\title{
REVIEW
}

\section{Sexual dimorphism of the somatotrophic axis}

\author{
K L Gatford, A R Egan, I J Clarke ${ }^{1}$ and P C Owens ${ }^{2}$ \\ Department of Agriculture and Resource Management, University of Melbourne, Parkville, Victoria 3052, Australia, ${ }^{1}$ Prince Henry's Institute of Medical \\ Research, PO Box 52, Clayton, Victoria 3158, Australia and 2Department of Obstetrics and Gynaecology, University of Adelaide, Adelaide, \\ South Australia 5005, Australia \\ (Requests for offprints should be addressed to K L Gatford, who is now at Department of Physiology, University of Adelaide, Adelaide, South Australia 5005, \\ Australia)
}

\section{Introduction}

The somatotrophic axis is one of the major hormonal systems regulating postnatal growth in mammals. Several aspects of this axis are sexually dimorphic, which might account for some of the sex differences in growth rate and body composition. This review will discuss male-female differences in the hormone levels, receptor concentrations and binding protein levels of this system. We will summarise sex differences in growth phenotype and then discuss differences in temporal profiles of growth hormone $(\mathrm{GH})$, responses to $\mathrm{GH}$ including plasma and tissue levels of insulin-like growth factors, factors that may affect $\mathrm{GH}$ responsiveness, and conclude by discussing sex differences in regulation of GH synthesis and secretion. The established and potential effects of gonadal steroids acting prenatally and postnatally on the somatotrophic axis will also be examined. Readers are also referred to previous reviews on sexual dimorphism and gonadal steroid effects on growth hormone secretion (Jansson et al. 1985, Devesa et al. 1991, Kerrigan \& Rogol 1992, Wehrenberg \& Giustina 1992, Chowen et al. 1996, Veldhuis 1996).

\section{The somatotrophic axis}

GH (also known as somatotrophin) is synthesised and secreted by the anterior pituitary gland in a pulsatile manner under the co-ordinate control of two hypothalamic neuropeptide hormones, GH-releasing factor (GRF) and somatostatin (somatotrophin release-inhibiting factor, SRIF). GH is a polypeptide hormone that exhibits sequence and structural homology between species and with the related hormones, prolactin and placental lactogen, all of which are proteins of $22-23 \mathrm{kDa}$ (Goffin et al. 1996). Most GH circulates as a monomer, although oligomeric, glycosylated and phosphorylated forms and variants arising from alternate splicing during transcription are also found (Lewis 1992). The half-life of the hormone differs between species, with a half-life of 6 min reported for rats (Badger et al. 1991) and one of around $25 \mathrm{~min}$ in humans (Holl et al. 1993). GRF and SRIF are produced by neurones in the arcuate nucleus and anterior periventricular nucleus respectively, and are carried in the hypophyseal portal circulation to the anterior pituitary. Two forms of GRF are synthesised, with 40 or 44 amino acids, and both monomers and dimers of the 14-amino acid SRIF are found in the circulation (Devesa et al. 1992). Adenylate cyclase activity in somatotrophs is increased after binding of GRF to its $G_{s}$ protein receptor, and decreased after binding of SRIF to its $G_{i}$ receptor. GRF therefore increases intracellular concentrations of cAMP, which stimulates GH secretion and synthesis in somatotrophs, whereas SRIF has the opposite effect (Bertherat et al. 1995). Alternating pulses of GRF and SRIF secretion into hypophyseal portal blood were first demonstrated in vivo by Plotsky \& Vale (1985) in male rats. A separate group of male rats that were sampled concurrently showed changes in $\mathrm{GH}$ secretion that were consistent with the observed GRF and SRIF concentrations. GH is secreted when the anterior pituitary is exposed to low concentrations of SRIF and high concentrations of GRF in hypophyseal portal blood (Tannenbaum \& Ling 1984, Hartman et al. 1993).

$\mathrm{GH}$ acts via its receptor to alter the metabolism of target tissues, such as liver and muscle (Carter-Su et al. 1996). Many of the growth responses to $\mathrm{GH}$ are believed to be the result of its stimulation of the synthesis of insulin-like growth factor-I (IGF-I), although growth hormone also has direct effects on cell growth and differentiation (Spagnoli \& Rosenfeld 1996). IGF-I is produced in most tissues and acts in an endocrine or paracrine manner to affect tissue metabolism through either the type 1 IGFreceptor or the insulin receptor (Cohick \& Clemmons 1993). This receptor cross-reactivity is the result of structural homology between IGF-I and insulin. IGF-II is also produced in many tissues, although its effects on metabolism are less well characterised. IGF-II binds to both the type 1 and type 2 IGF receptors, but not to the insulin receptor, and the type 1 IGF receptor is believed to mediate most of the biological actions of IGF-II (Cohick \& Clemmons 1993). The IGF-binding proteins are a family of at least seven proteins that bind to IGF-I and IGF-II, 
and which are found both in extracellular fluids and in association with cell surfaces or extracellular matrix (Clemmons 1996, Oh et al. 1996). Binding to IGFbinding proteins increases the half-life of IGFs and, because they have greater binding affinities for IGFs than the type 1 IGF receptor, they also alter the biological activity of the IGFs (Clemmons 1996). This review discusses changes in total plasma IGFs - that is, those occurring after separation of IGFs from IGF-binding proteins. IGF-binding protein-3 is the major IGF-binding protein in adult blood.

\section{Sexual dimorphism of growth phenotype}

Postnatal body weight and composition differ between males and females in a large number of mammalian species, but the ontogeny of these changes is species specific. In humans, other primates, rats and rabbits, height gain or rate of weight gain, or both, become sexually dimorphic around the time of puberty (reviewed by Tanner 1962, Edén 1979). However, in cattle and sheep, rates of growth are greater in males than in females from early postnatal life, such that differences in live weight develop before puberty (Brody et al. 1926, Fourie et al. 1970, Gatford et al. 1996). Sex differences in body composition also arise at puberty in humans, rats and rabbits, when males more rapidly gain muscle and bone and lose fat, whereas females have much smaller gains in muscle and bone and large gains in fat (reviewed by Tanner 1962). This results in a greater proportion of total body weight as fat in adult females. For example, in one population the body fat contents of 25-year-old men and women were estimated as $14 \%$ and $23 \%$ of total body weight respectively (Brozek 1967).

Adult males are generally heavier and leaner than adult females, but species differ in the age at which sex differences in the rate and composition of gain occur.

\section{Sexual dimorphism in temporal profiles of circulating GH}

Measurement of GH concentration in samples of blood serum or plasma collected at frequent intervals from cannulated subjects has shown that circulating concentrations of GH vary episodically (Fig. 1) (Davis et al. 1977, Edén 1979). Species differ both in the temporal profiles of circulating $\mathrm{GH}$ concentration and in how these profiles differ between sexes. Humans are unusual in that mean plasma GH concentrations and $\mathrm{GH}$ pulse amplitude are greater in adult females than in adult males (Zadik et al. 1985, Ho et al. 1987, Albertsson-Wikland \& Rosberg 1988, Costin et al. 1989, Winer et al. 1990, Rose et al. 1991). In contrast, mean GH concentrations and GH pulse amplitude in blood are greater in adult males than in adult females in rats (Tannenbaum \& Martin 1976, Edén 1979, Jansson et al. 1984, Gabriel et al. 1992, Leidy et al. 1993), mice (MacLeod et al. 1991), cattle (Plouzek \& Trenkle 1991, Röpke et al. 1994), horses (Thompson et al. 1994) and chickens (Pampori \& Shapiro 1994). Mean plasma $\mathrm{GH}$ concentrations are also greater in male than in female in late-gestation fetuses in sheep and pigs (Bassett \& Gluckman 1986, Bauer \& Parvizi 1996) and in prepubertal sheep (Gatford et al. 1996, 1997a). Several studies in pigs have also revealed greater mean plasma GH concentrations in males than in females (Dubreuil et al. 1987, Campbell \& Taverner 1988, Louveau et al. 1991, Kraetzl et al. 1994), but this is not a universal observation (Owens et al. 1991, Buonomo \& Klindt 1993). Interpulse plasma $\mathrm{GH}$ concentrations are greater in female rats than in males (Tannenbaum \& Martin 1976, Edén 1979, Jansson et al. 1984, Gabriel et al. 1992, Leidy et al. 1993) and the same is true in mice (MacLeod et al. 1991) and humans (Winer et al. 1990). In contrast, interpulse plasma GH is greater in males than females in cattle (Plouzek \& Trenkle 1991), chickens (Pampori \& Shapiro 1994) and prepubertal sheep (Gatford et al. 1996, 1997a). Plasma GH pulse frequency does not differ between sexes in humans (Winer et al. 1990), chickens (Pampori \& Shapiro 1994) or prepubertal sheep (Gatford et al. 1996, 1997a), whereas, in rodents, $\mathrm{GH}$ pulses are less frequent in males than in females (Tannenbaum \& Martin 1976, Edén 1979, Jansson et al. 1984, MacLeod et al. 1991, Gabriel et al. 1992, Leidy et al. 1993). In cattle (Plouzek \& Trenkle 1991) and in horses (Thompson et al. 1994) plasma GH pulses are more frequent in males than in females. In addition to differences in GH pulse frequency and amplitude, pulsatile $\mathrm{GH}$ secretion is less regular in female rats than in males (Edén 1979, Painson \& Tannenbaum 1991, Pincus et al. 1996).

The timing of the onset of sex differences in circulating profiles of $\mathrm{GH}$ also varies between species. In humans (Zadik et al. 1985, Albertsson-Wikland \& Rosberg 1988, Costin et al. 1989, Rose et al. 1991) and rats (Edén 1979, Jansson et al. 1984, Gabriel et al. 1992, Leidy et al. 1993), patterns and mean concentrations of circulating GH do not differ between the sexes before puberty but become apparent during the peripubertal period, concomitant with the appearance of sex differences in growth rate. In sheep, however, both growth rate and temporal profiles of $\mathrm{GH}$ in plasma are sexually dimorphic before puberty (Gatford et al. 1996). Sex differences in the pulsatile profile of circulating $\mathrm{GH}$, and in mean $\mathrm{GH}$ concentrations, are likely to contribute to sex differences in growth and other responses to $\mathrm{GH}$. Infusion of $\mathrm{GH}$ in male rats at a constant rate produces smaller increases in growth rate and circulating concentrations of IGF-I, but is more effective at increasing hepatic $\mathrm{GH}$ receptor numbers and circulating $\mathrm{GH}$-binding protein concentrations, than infusion of the same $\mathrm{GH}$ dose as a series of pulses (Maiter et al. 1988, 1992, Bick et al. 1990, 1992). A recent study in rats has shown that growth responses are more sensitive to stimulation by the pulsatile component of a $\mathrm{GH}$ infusion, whereas hepatic $\mathrm{GH}$ receptor and plasma 


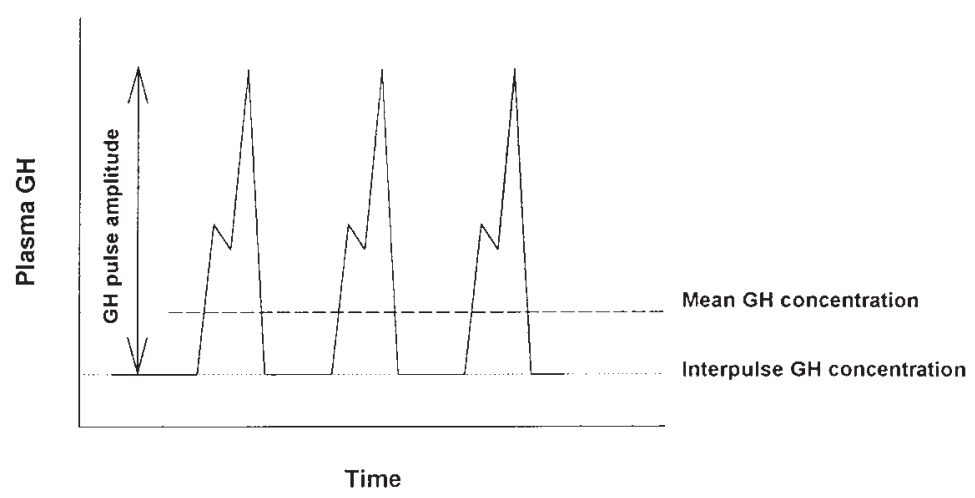

Figure 1 Temporal profile of circulating GH concentrations.

GH-binding protein concentrations are sensitive to the continuous component (Gevers et al. 1996). Thus, in rats, the greater amplitude and lower frequency of GH pulses in males may be more effective in stimulating growth than the profile observed in females.

The in vivo effects of endogenous and exogenous gonadal steroids on profiles of circulating GH are well documented. Mean plasma GH concentration, area under the GH profile and $\mathrm{GH}$ pulse amplitude are all increased by androgens in humans (Illig \& Prader 1970, Parker et al. 1984, Ulloa-Aguirre et al. 1990), rats (Jansson et al. 1984, 1985), cattle (Plouzek \& Trenkle 1991, Schwarz et al. 1992, Röpke et al. 1994), sheep (Davis et al. 1977, Gatford et al. 1996), pigs (Dubreuil et al. 1989) and chickens (Pampori \& Shapiro 1994). In humans, administration of testosterone to males increases mean plasma $\mathrm{GH}$ and $\mathrm{GH}$ secretion rate by increasing $\mathrm{GH}$ pulse amplitude (Illig \& Prader 1970, Liu et al. 1987, Ulloa-Aguirre et al. 1990), whereas in rats androgens also reduce interpulse $\mathrm{GH}$ concentrations (Jansson et al. 1984, 1985).

Oestrogen treatment also increases mean plasma GH concentrations in humans (Carlson et al. 1973, Wiedemann et al. 1976, Ho et al. 1996), castrate female macaques (Bethea 1991), intact female baboons (Copeland et al. 1984), sheep (Davis et al. 1977) and cattle (Breier et al. 1988). In primate species, endogenous oestrogens appear to be more important than endogenous androgens for regulation of circulating GH. Most studies in humans have reported positive correlations between $\mathrm{GH}$ pulse amplitude and serum concentrations of free oestradiol (Ho et al. 1987, Faria et al. 1992), but not between mean plasma $\mathrm{GH}$ and plasma testosterone concentrations (Thompson et al. 1972, Butenandt et al. 1976, Ho et al. 1987). However, Iranmanesh et al. (1991) reported that GH secretion, pulse frequency and pulse amplitude were negatively correlated with free testosterone and not related to serum oestradiol in healthy men. In non-primates, endogenous oestrogen status has less effect on circulating $\mathrm{GH}$ profiles than has the endogenous androgen status.
Ovariectomy of cows does not alter the temporal pattern of circulating GH (Plouzek \& Trenkle 1991). In rats, circulating patterns of $\mathrm{GH}$ do not change with stage of the oestrous cycle (Clark et al. 1987), but ovariectomy produces a small increase in GH pulse amplitude (Jansson et al. 1984, Clark et al. 1987) and oestrogen treatment increases interpulse GH concentrations in males (Jansson et al. 1983). This suggests that sex differences in endogenous oestrogen production might contribute to the smaller GH pulse amplitude and greater interpulse GH concentrations in females compared with males in this species. Oestrogen receptor-mediated pathways have been proposed as a mechanism for the effects of both steroids on circulating GH (Devesa et al. 1991, Metzger et al. 1994). However, oestrogens and androgens have different effects on circulating patterns of $\mathrm{GH}$ in humans. Whereas androgens increase mean plasma GH by increasing GH pulse amplitude, without changing interpulse GH concentrations or GH pulse frequency, oestrogens increase mean plasma GH by increasing interpulse GH concentrations, GH pulse amplitude, pulse frequency, or combinations of these (Dawson-Hughes et al. 1986, Mauras et al. 1990).

In addition to the effects of steroids on circulating $\mathrm{GH}$ after puberty, androgens and oestrogens act before puberty to exert permanent effects on circulating patterns of $\mathrm{GH}$ in later life. In the rat, in which sexual differentiation of brain centres regulating growth occurs shortly after birth, neonatal, but not prepubertal, castration of male rats decreases their GH pulse amplitude and increases their interpulse GH concentrations as adults (Jansson \& Frohman 1987, Jansson et al. 1984). Neonatal gonadectomy of female rats decreased their interpulse $\mathrm{GH}$ concentrations and increased their $\mathrm{GH}$ pulse amplitude as adults, resulting in a temporal pattern of $\mathrm{GH}$ in the circulation that was more like that of males and increased their growth rates in later life (Jansson et al. 1984). However, in female sheep and cattle, in which sexual differentiation of growth regulation occurs before birth, prenatal androgen exposure increased postnatal growth and plasma IGF-I, but did not alter circulating patterns of GH (Klindt et al. 1987, Aldrich et al. 
1996), implying that the IGF-I response to GH was increased.

In non-primate species, mean circulating GH concentrations are greater in males than in females, whereas in primate species, mean circulating GH concentrations are greater in females than in males. Sex differences in circulating GH profiles usually become apparent over the same period as sex differences in growth. Either androgen or oestrogen treatment increases mean circulating GH in most species, and androgen and oestrogen can also act before puberty to alter circulating profiles of GH permanently in later life.

\section{Sexual dimorphism in responses to $\mathrm{GH}$}

\section{Growth rate and body composition}

Sexual dimorphism in growth rate and body composition have been discussed above. Sex differences in circulating GH profiles may be a mechanism by which steroid hormones produce these differences, at least in nonprimates. However, studies in which exogenous $\mathrm{GH}$ has been administered have also produced evidence of sex differences in responsiveness to $\mathrm{GH}$. In GH-deficient adults, GH treatment produced greater increases in plasma IGF-I and total body water in men than in women (Johannsson et al. 1996, Burman et al. 1997). Conversely, GH treatment of growing pigs produced greater increases in growth and protein deposition in females than in males (Campbell et al. 1990). Potential mechanisms for sex differences in growth and composition responses to $\mathrm{GH}$ are discussed below.

\section{Insulin-like growth factor-I}

The insulin-like growth factors are hormones that are believed to mediate many of the effects of $\mathrm{GH}$ on tissue growth and metabolism (Cohick \& Clemmons 1993). If sexual dimorphism at the level of circulating $\mathrm{GH}$ is the mechanism responsible for sexually dimorphic patterns of growth, one would also expect sex differences at the level of the insulin-like growth factors and their binding proteins.

Plasma concentrations of IGF-I are greater in males than females in postpubertal rats (Gabriel et al. 1992, Hu et al. 1993), mice (Blair et al. 1987), pre- and postpubertal sheep (Roberts et al. 1990, Medrano \& Bradford 1991, Gatford et al. 1996, 1997b), cattle (Bishop et al. 1989, Hannon et al. 1991, Schwarz et al. 1992, Röpke et al. 1994, Davis et al. 1995), late-gestation fetal and postnatal pigs (Owens et al. 1990, Lamberson et al. 1995, Bauer \& Parvizi 1996) and in turkeys from 1 week of age (Bacon et al. 1993). In contrast, most, although not all (Juul et al. 1994) studies in primates have found that plasma IGF-I concentrations are greater in postpubertal females than in males (Copeland et al. 1985, Merimee et al. 1987, Yamamoto et al. 1991,
Schwartz \& Kemnitz 1992). Plasma IGF-I concentrations in children are also greater in females than in males before and during puberty (Merimee et al. 1991, Juul et al. 1994). The direction of sex differences in IGF-I is generally consistent with that associated with $\mathrm{GH}$, although meattype chickens appear to be an exception in early postnatal life, with greater $\mathrm{GH}$ and growth rates, but lower plasma IGF-I concentrations in males than in females in the first few weeks after hatching. However, by 7 weeks of age, plasma IGF-I concentrations are similar, or greater, in males than in females (Johnson et al. 1989, Scanes et al. 1989, Ballard et al. 1990, Decuypere et al. 1993). As with $\mathrm{GH}$, the developmental stage at which plasma IGF-I concentrations become sexually dimorphic varies between species. Plasma IGF-I concentrations do not differ between sexes in prepubertal rats and mice (Blair et al. 1987, Gabriel et al. 1992), but are sexually dimorphic in prepubertal humans (Merimee et al. 1991, Juul et al. 1994), lambs (Gatford et al. 1996) and pigs (Owens et al. 1991).

Androgens and oestrogens appear to affect plasma concentrations of IGFs via different mechanisms and their effects differ between species. Androgens are believed to affect circulating IGF-I indirectly, via increased circulating $\mathrm{GH}$ concentrations, as GH deficiency in rats and humans abolishes the increase in plasma IGF-I at puberty or after androgen treatment (Parker et al. 1984, Crawford et al. 1994). Androgen treatment does not affect the plasma IGF-I response to a $\mathrm{GH}$ challenge in prepubertal boys (Craft \& Underwood 1984). The effects of oestrogens on circulating IGF-I and the mechanism for these effects may differ between sexes and species. In ovariectomised female rats, oestrogens increase circulating $\mathrm{GH}$, but reduce circulating IGF-I concentrations by inhibiting the hepatic IGF-I synthetic response to GH (Murphy \& Freisen 1988, Borski et al. 1996). Oestrogen treatment of male cattle increases plasma concentrations of both IGF-I and GH (Breier et al. 1988, Coxam et al. 1990). In humans, the reported effects of oestrogens on circulating IGF-I are extremely variable. Endogenous and administered oestrogen are variously reported to decrease (e.g. Wiedemann et al. 1976, Weissberger et al. 1991), have no effect (e.g. Wang et al. 1995) or increase (e.g. Weissberger et al. 1991, Juul et al. 1995a) plasma IGF-I in women and girls. The observed IGF-I response may depend on whether the oestrogen was endogenous or exogenous, the route of administration for exogenous oestrogen and the time course over which circulating IGF-I was monitored. In female chimpanzees, circulating IGF-I concentrations are less strongly correlated with plasma oestrogen than with plasma testosterone, whereas in males of this species plasma oestrogen and IGF-I concentrations are not correlated (Copeland et al. 1985).

Exposure to steroids during neonatal or prenatal life also modifies circulating concentrations of IGF-I in later 
postnatal life. For example, in female lambs that were chronically exposed to increased testosterone as fetuses as a result of maternal testosterone implants, postnatal plasma IGF-I concentrations were increased by $29 \%$ compared with those in control lambs (DeHaan et al. 1990a). Prenatal exposure to androgen consistently increases postnatal growth rates and circulating IGF-I and decreases fat deposition, in male and female cattle and sheep (Klindt et al. 1987, DeHaan et al. 1988, 1990a,b, Jenkins et al. 1988, Aldrich et al. 1996). However, prenatal exposure to androgen did not alter circulating patterns of $\mathrm{GH}$ in female cattle (Aldrich et al. 1996) and sheep (Klindt et al. 1987), implying that prenatal exposure to androgen does not increase circulating IGF-I by stimulating GH in these species. Although neonatal exposure to steroids permanently affects growth and growth hormone secretion in the rat (Jansson et al. 1984, Jansson \& Frohman 1987), the effects of neonatal steroid status or administration on adult plasma IGF-I concentrations in this species have not been reported.

In non-primate species, plasma IGF-I concentrations are greater in males than in females, whereas, in primate species, plasma IGF-I concentrations are greater in females than in males. Androgens increase plasma IGF-I concentrations indirectly, through increasing plasma GH, but the effects of oestrogens are variable. Sex differences in IGF-I support the hypothesis that sex differences in growth may be partially the result of gonadal steroids acting to produce sexually dimorphic patterns of circulating GH. However, studies in cattle and sheep also suggest that steroids may affect circulating IGF-I independent of effects on GH.

\section{Insulin-like growth factor-II}

Plasma IGF-II concentrations are reported not to differ between sexes in children, adolescent or young adult humans (Merimee et al. 1987, Juul et al. 1995b). In prepubertal lambs, plasma IGF-II concentrations were similar in females and males at 12 weeks of age and greater in females than in males at 23 weeks of age (Gatford $e t$ al. 1996). Plasma IGF-II in prepubertal pigs was also greater in females than in males (Owens et al. 1993). In young meat-type chickens, sex differences in plasma IGF-II concentrations follow an ontogenic pattern similar to that of IGF-I, with greater IGF-II in females than males at 2 weeks of age, but not at later ages (Scanes et al. 1989, Decuypere et al. 1993). The effect of androgens on IGF-II differs between species. In neonatal rats, androgens decrease hepatic IGF-II mRNA concentrations (Martinoli \& Pelletier 1991). Plasma concentrations of IGF-II are not affected by castration in male lambs (Gatford et al. 1996), but are increased by castration in male pigs (Owens et al. 1993).

Studies to date indicate that plasma IGF-II concentrations are either similar or greater in females compared with males. Androgens may inhibit IGF-II synthesis in some, although not necessarily all, species.
Insulin-like growth factor-binding proteins

Plasma concentrations of IGF-binding protein-3, the main carrier of IGFs in blood in postnatal life, are positively regulated by $\mathrm{GH}$ (Clemmons 1996). Consistent with differences in circulating $\mathrm{GH}$, plasma IGF-binding protein-3 concentrations are greater in women than in men (Juul et al. 1995b, Harrela et al. 1996) and greater in male than in female growing lambs (Gatford et al. 1996). Circulating IGF-binding protein-1 concentrations are greater in female than in male fasted humans and rats, but these differences are reduced or abolished by feeding (Rutanen et al. 1982, Yeoh \& Baxter 1988, Lewitt et al. 1994, Juul et al. 1995b). Plasma IGF-binding protein-2 concentrations do not differ between sexes in humans and pigs before or after puberty (Buonomo \& Klindt 1993, Juul et al. 1995b).

In male humans and sheep, androgens positively regulate circulating concentrations of IGF-binding protein-1 and IGF-binding protein-3 (Erfurth et al. 1996, Gatford et al. 1996, Pfeilschifter et al. 1996). Plasma IGF-binding protein-3 is positively regulated by androgens in pubertal, but not sexually mature, male chimpanzees (Crawford \& Handelsman 1996). In male cattle, although circulating concentrations of IGF-binding protein-3 increase and those of IGF-binding protein-2 decrease at puberty, these changes are not affected by perturbations of circulating testosterone (Renaville et al. 1996).

Oestrogens may chronically, but not acutely, reduce plasma concentrations of IGF-binding protein-3. Oestrogen treatment reduces plasma IGF-binding protein-3 concentrations in female rats and pigs (Lee et al. 1993, Kalu et al. 1994), but plasma IGF-binding protein-3 does not fluctuate with ovarian cyclicity in women or in female cattle (Funston et al. 1995, Wang et al. 1995). Other IGF-binding proteins may be positively regulated by oestrogens. In women, plasma IGF-binding protein-1 concentrations increase in association with the preovulatory peak in circulating oestrogen (Wang et al. 1995) and after oestrogen treatment (Suikkari et al. 1991). Plasma IGFbinding protein-2 is positively regulated by oestrogens in female cattle (Vestergaad et al. 1995) but is not affected by oestrogen treatment in female pigs (Lee et al. 1993).

Sex differences in circulating concentrations of IGF-binding protein-3 are consistent with differences in GH. Limited data suggest that androgens may increase circulating concentrations of IGF-binding protein-3 and -1, whereas oestrogens increase circulating concentrations of IGF-binding proteins-1 and -2 and decrease circulating concentrations of IGF-binding protein-3.

\section{Sexual dimorphism in factors affecting GH responsiveness}

\section{GH receptor}

The GH receptor is a member of the cytokine/ haematopoietin receptor superfamily. Binding of GH to 
the $\mathrm{GH}$ receptor induces receptor dimerisation and activation of the tyrosine kinase, JAK2, which in turn activate signalling molecules, including Stat transcription factors, Src homologous collagen protein (SHC) and insulin receptor substrates 1 and 2. Downstream events include release of second messengers, including diacylglycerol, calcium and nitric oxide, and activation of enzymes, including mitogen-activated protein kinase, protein kinase $\mathrm{C}$, phospholipase $\mathrm{A}_{2}$ and phosphatidylinositol 3'-kinase, which affect the function of the target cell (Argetsinger \& Carter-Su 1996). Genetic defects of the GH receptor in Laron syndrome cause GH resistance and result in dwarfism, obesity and low serum concentrations of IGF-I (Laron 1993). As a functional GH receptor is necessary for GH to produce responses in target tissues, sex differences in $\mathrm{GH}$ receptor numbers or affinity might produce differences in response to $\mathrm{GH}$.

In the rat, hepatic $\mathrm{GH}$ binding capacity and receptor numbers are two-fold greater in males than in females after puberty (Kelly et al. 1974, Postel-Vinay 1976, Maes et al. 1983, Tiong \& Herington 1991, Carmignac et al. 1993a, b). Despite this difference in $\mathrm{GH}$ binding activity, total hepatic $\mathrm{GH}$ receptor mRNA concentrations do not differ between sexes in the rat (Mathews et al. 1989, Carlsson et al. 1990a, Tiong \& Herington 1991, Möldrup et al. 1993, Baumbach \& Bingham 1995), although mRNA for a liver-specific receptor subtype, $\mathrm{GHR}_{1}$, is expressed at greater concentrations in female rats than in males (Baumbach \& Bingham 1995). In the adult rabbit, the abundance of neither hepatic GH binding nor GH receptor mRNA differs between sexes (Kelly et al. 1974, Tiong et al. 1989).

In rats, testosterone treatment does not affect hepatic GH binding (Carmignac et al. 1993a), but oestrogen treatment induces $\mathrm{GHR}_{1}$ transcripts, resulting in increased hepatic GH binding (Carmignac et al. 1993a, Gabrielsson et al. 1995, Bennett et al. 1996). The effect of oestrogen on GH receptors differs between species. Physiological doses of oestrogen decrease $\mathrm{GH}$ receptor expression and $\mathrm{GH}$ binding in rabbit liver (Domene et al. 1994). Decreased plasma GH binding protein concentrations in humans treated with oestrogen probably also reflect decreased GH receptor numbers (Kobayashi et al. 1994, Tato et al. 1995).

Sex differences in hepatic GH binding and expression of the GH receptor gene vary between species. A liver-specific receptor subtype in rats, $G H R_{1}$, is expressed at greater concentrations in female than in males and is upregulated by oestrogen. However, in other species, oestrogen appears to downregulate the $\mathrm{GH}$ receptor.

\section{GH-binding protein}

GH-binding protein is a truncated form of the $\mathrm{GH}$ receptor, corresponding to the extracellular ligand-binding domain (Leung et al. 1987). In rats and humans, highaffinity GH-binding proteins in plasma form complexes with some of the $\mathrm{GH}$ in blood and are proposed to function as a $\mathrm{GH}$ reservoir and to modulate the action of GH at its receptor (Amit et al. 1992, Baumann 1994, Herington et al. 1994, Bingham et al. 1994). In normal adult rats, circulating concentrations of GH-binding protein are two- or threefold greater in females than in males (Carmignac et al. 1992, Leung et al. 1994). Studies in humans have also shown greater concentrations of $\mathrm{GH}$-binding protein in blood from females than in that from males (Ho et al. 1993, Rajkovic et al. 1994), although earlier studies did not find such differences, probably because of the use of less sensitive detection methods (Merimee et al. 1991, Mercado et al. 1993). In cattle and sheep, GH-binding protein is present in lower concentrations in plasma than are observed in rats or humans, and is not believed to have an important role in GH metabolism (Amit et al. 1992, Davis et al. 1992, Bingham et al. 1994). Sex differences have not been investigated in these species. In chickens, serum GH-binding protein concentrations do not differ between the sexes (Tobar-Dupres et al. 1993). In the rat, the lower concentrations of circulating GH-binding protein, combined with greater GH pulse amplitude, may produce more free circulating GH during GH-secretory episodes in male than in female rats, resulting in sex differences in the availability of $\mathrm{GH}$ (Leung et al. 1994).

Because the GH-binding protein is derived either by alternate splicing of $\mathrm{GH}$ receptor $\mathrm{mRNA}$ as in rats (Baumbach et al. 1993), or by proteolytic cleavage of the cell-surface $\mathrm{GH}$ receptor protein as in humans (Sotiropoulos et al. 1993), it is not surprising that gonadal steroids have similar effects both on GH-binding protein concentrations in blood and GH receptor numbers in liver. Physiological doses of androgens do not affect concentrations of GH-binding protein in rats (Carmignac et al. 1993a) or men (Ip et al. 1995). However, pharmacological doses of testosterone decrease serum GH-binding protein concentrations in hypogonadal men, independent of GH status (Ip et al. 1995). Oestrogens increase hepatic concentrations of $\mathrm{GH}$-binding protein mRNA and circulating concentrations of $\mathrm{GH}$-binding protein in rats (Carmignac et al. 1993a, Gabrielsson et al. 1995, Bennett et al. 1996). In humans, circulating GH-binding protein concentrations are generally negatively correlated with endogenous oestrogen concentrations and are reduced by physiological doses of oestrogen (Massa et al. 1993, Kobayashi et al. 1994, Tato et al. 1995), although Klein et al. (1996) did not find that plasma GH-binding protein concentrations differed with stage of the ovulatory cycle in women. Conversely, pharmacological doses of oestrogen increase plasma GH-binding protein concentrations (Weissberger et al. 1991, Kelly et al. 1993, Ho et al. 1993, Massa et al. 1993, Rajkovic et al. 1994).

Circulating concentrations of GH-binding protein are greater in females than in males in both rats and humans, and may 
decrease the availability of circulating GH in females. The effects of gonadal steroids on GH-binding protein are species specific and differ between physiological and pharmacological doses.

\section{Metabolic clearance rate of $\mathrm{GH}$}

Differences in responsiveness to either endogenous or exogenous GH may also be a result of differences in turnover of GH in blood. Rosenbaum \& Gertner (1989) reported that the metabolic clearance rate of $\mathrm{GH}$ was $40 \%$ greater in adult men than in adult women, whereas differences in GH clearance were not apparent in prepubertal children. They calculated that the difference in $\mathrm{GH}$ clearance rate in adults might account for most of the observed difference in mean circulating GH concentrations. However, differences in metabolic clearance rate correspond to differences in GH half-life only if the distribution volume of $\mathrm{GH}$ does not differ between sexes, and this may not be the case, given sex differences in circulating concentrations of GH-binding protein. In humans, androgen treatment did not alter GH clearance in prepubertal boys, but endogenous steroids may affect $\mathrm{GH}$ clearance, as the half-life of GH in young men is negatively correlated with serum oestradiol concentrations (Holl et al. 1993) and positively correlated with serum testosterone (Iranmanesh et al. 1991). Conversely, in rats, the steady-state clearance of $\mathrm{GH}$ is decreased by oestrogen and increased by testosterone (Badger et al. 1991). In cattle, the metabolic clearance rate of GH did not differ between entire and castrate males and entire females (Plouzek \& Trenkle 1991). The metabolic clearance rate of GH was increased by ovariectomy, but not altered by oestrogen treatment in castrate males (Gopinath \& Kitts 1984, Plouzek \& Trenkle 1991).

Sex differences in the clearance rate of GH differ between species, and require further investigation.

\section{Sexual dimorphism in the regulation of GH secretion and synthesis}

Sexual dimorphism in circulating patterns of GH could be due to differences in anterior pituitary synthesis and secretion of $\mathrm{GH}$ as a result of sex differences in either hypothalamic secretion of GRF and SRIF or the pituitary $\mathrm{GH}$ response to these hormones. Technical difficulties have prevented the simultaneous measurement of $\mathrm{GH}$, GRF and SRIF in animals with normal feedback systems. The evidence for differences in hypothalamic GRF and SRIF secretion is therefore largely indirect. However, in vivo and in vitro evidence suggests there are sex differences in anterior pituitary responsiveness to GRF and SRIF.

\section{Pituitary sensitivity to GRF and SRIF}

In vivo $\mathrm{GH}$ responses to i.v. GRF are greater in males than females in rats (Wehrenberg et al. 1985, Arsenijevic et al.
1987), cattle (Plouzek \& Trenkle 1991) and horses (Thompson et al. 1994). However, in vivo human studies have reported either greater pituitary sensitivity or greater pituitary responsiveness to GRF in females than in males (Gelato et al. 1984, Lang et al. 1987, Benito et al. 1991, Pietschmann et al. 1991). In rhesus monkeys, the increase in $\mathrm{GH}$ in response to increasing GRF dose rate did not differ between males and females (Styne 1991). In vitro studies suggest that sex differences in pituitary sensitivity to GRF are partially responsible for differences in the in vivo GH response to GRF. Basal and GRF-stimulated GH secretion rates in intact perfused anterior pituitaries, anterior pituitary cell preparations and individual somatotrophs are greater in those from male rats than in those from female rats (Cronin \& Rogol 1984, Evans et al. 1985, Hoeffler \& Frawley 1986, Critchlow et al. 1986, Ho et al. 1986, Kerrigan et al. 1989). The observation that GRF receptor expression in female rats was only $15 \%$ of that observed in male rats is consistent with these observations (Ono et al. 1995).

Sex differences in pituitary responsiveness to SRIF have also been reported. In the rat, GRF-stimulated GH secretion is inhibited by lower concentrations of SRIF in somatotrophs from females than from males (Critchlow et al. 1986, Kerrigan et al. 1989). This suggests that differences in pituitary responsiveness to GRF, and possibly also SRIF, are involved in producing sexually dimorphic profiles of $\mathrm{GH}$.

Gonadal steroids have been shown to affect GHsecretory responses to GRF and SRIF. In vivo androgen treatment of rats increases the GH-secretory response to exogenous GRF measured in vivo (Wehrenberg et al. 1985) and in vitro (Evans et al. 1985, Wehrenberg et al. 1985, Ohlsson et al. 1987, Batson et al. 1989). In humans, androgens also increase $\mathrm{GH}$ secretion in reponse to GRF, measured in vivo, and this increase can be prevented by oestrogen receptor blockade (Lima et al. 1989). In rats, in vivo administration of oestrogen either decreases (Evans et al. 1985, Ohlsson et al. 1987, Shulman et al. 1987) or fails to affect (Wehrenberg et al. 1985, Painson et al. 1992) in vivo and in vitro GH release after GRF administration. The activity of adenyate cyclase in the anterior pituitary, which positively regulates GH synthesis and secretion, is also enhanced by in vivo administration of testosterone and inhibited by oestrogen in the rat (Gabriel et al. 1993). Whereas in vivo pituitary responses to steroid treatment may partially reflect changes in hypothalamic GRF and SRIF secretion, in vitro studies confirm that the pituitary is a site at which gonadal steroids exert effects on GH secretion, at least in the rat.

The reported in vitro effects of gonadal steroids on basal GH synthesis and secretion are contradictory. In vitro steroid treatment has been reported to have no effect on basal GH secretion by cultures of anterior pituitary cells 
from rats (Fukata \& Martin 1986, Webb et al. 1983) and cattle (Hassan et al. 1992). Similar treatments have been reported to increase basal GH secretion in anterior pituitary cell cultures from female rats (Simard et al. 1986), whereas the reverse has been reported for male rats (Hertz et al. 1989). In macaques, in vitro oestrogen treatment increased basal GH secretion in cultures of pituitary cells from juvenile males, but not in anterior pituitary cell cultures from juvenile females or adult males and females (Bethea 1991). GH synthesis in anterior pituitary cells was decreased by in vitro testosterone or oestrogen treatment in male rat cells (Hertz et al. 1989), but increased by oestrogen treatment in female rat cells (Simard et al. 1986). The in vitro effects of gonadal steroids on pituitary GHsecretory responses to GRF and SRIF have been demonstrated more consistently, and depend on the sex of the animal from which the anterior pituitary cells were derived. In anterior pituitary cells from male rats and calves, in vitro preincubation with androgens enhanced the GH-secretory response to GRF and the inhibition of GH secretion by SRIF (Hertz et al. 1989, Hassan et al. 1992). In vitro treatment of male anterior pituitary cells with oestrogens has been reported either not to affect (Hertz et al. 1989, Hassan et al. 1992) or to enhance the GH-secretory response to GRF (Webb et al. 1983). In female rat anterior pituitary cells, the GH-secretory response to GRF has been reported to be enhanced by in vitro addition of oestrogen, but not of testosterone (Simard et al. 1986, Hertz et al. 1989), although Fukata \& Martin (1986) found no change in pituitary responsiveness to GRF or SRIF after oestrogen or testosterone pretreatment. In male rat anterior pituitary cells, oestrogens prevented SRIF suppression of basal, but not GRF-stimulated, GH secretion (Hertz et al. 1989).

Several studies suggest that, in addition to these direct actions of steroids at the pituitary, the sensitivity of the pituitary to GRF and SRIF may also be permanently reset by the actions of gonadal steroids before puberty. GHsecretory responses to GRF and SRIF were sexually dimorphic in anterior pituitary cells from adolescent rats that were gonadectomised prepubertally (Hertz et al. 1989). The in vitro GH-secretory response to GRF in adult male rats was suppressed more effectively by neonatal than prepubertal gonadectomy, and androgen treatment in adulthood was able to reverse this effect only after prepubertal gonadectomy (Ohlsson et al. 1987, Fishman et al. 1993). Similarly, neonatal administration of androgen, but not oestrogen, to female rats that were gonadectomised later in life enhanced their in vivo GH-secretory responses to i.v. GRF as adults (Aguilar \& Lopez 1988).

Pituitary sensitivity to GRF appears to be greater in males than in females in non-primates, but greater in female than in male primates. Androgen administration enhances, and oestrogen administration inhibits, GH-secretory responses to GRF in vivo, but the effects of these steroids on the GH-secretory response to GRF in vitro depend on the sex of the animal from which the somatotrophs were obtained. In rats, exposure to androgens before puberty enhances GH-secretory responses to GRF in later life.

\section{GH-releasing factor synthesis and secretion}

Patterns of circulating GRF in hypothalamic-hypophyseal portal blood in males and females have not been reported for any species. However, in vivo studies in the rat have compared the effects of removal of GRF on circulating $\mathrm{GH}$ in males and females using either immunoneutralisation of endogenous GRF or suppression of GRF secretion by neonatal treatment with monosodium glutamate, which causes permanent lesions in the GRF-secreting regions of the hypothalamus. Both immunoneutralisation and GRF deficiency decrease GH pulse amplitude in blood in both sexes and decrease interpulse concentrations of circulating $\mathrm{GH}$ in females, but not in males. This implies that interpulse GH concentrations in the female rat are primarily regulated by GRF, not SRIF (Wehrenberg et al. 1982, Maiter et al. 1991a, Ono et al. 1991, Painson \& Tannenbaum 1991). Lower interpulse GH concentrations in the male rat are postulated to be due to either greater SRIF secretion or lower GRF secretion between GH pulses than occurs in females. To date, the sheep is the only species in which GH and GRF have been measured concurrently and those studies show only partial concordance between GRF and GH pulses, possibly because of intermittent blockage of GH secretion by SRIF pulses (Frohman et al. 1990, Thomas et al. 1991, Fletcher et al. 1996).

Hypothalamic GRF content is greater in male than in female adult rats (Gabriel et al. 1989, 1993, Maiter et al. 1990, 1991a, Ono et al. 1995) and hypothalamic GRF mRNA concentrations are two to three times greater in males than in females (Argente et al. 1991, Maiter et al. 1991b. Mizobuchi et al. 1991, Hasegawa et al. 1992, Chowen et al. 1993). Similarly, in prepubertal lambs, the hypothalamic GRF content is approximately $50 \%$ greater in males than in females (Gatford et al. 1997a). Regulation of GRF synthesis and secretion also differs between sexes in rats. Release of GRF by slices of rat hypothalamic tissue in response to potassium administration is greater in males than in females (Ono et al. 1995, Ge et al. 1989). Hypothalamic GRF protein and mRNA are more sensitive to feedback inhibition by GH in male rats than in females (Maiter et al. 1990, 1991b).

Sex differences in GRF content may be the result of gonadal steroid action. Androgen treatment in vivo has been reported to increase hypothalamic GRF protein and mRNA content in adult rats of both sexes (Zeitler et al. 1990, Fernandez et al. 1992, Hasegawa et al. 1992, Chowen et al. 1993). However, others have reported no change in hypothalamic GRF mRNA or GRF content 
after gonadectomy or testosterone treatment of adult male or female rats (De Gennaro Colonna et al. 1991, Gabriel et al. 1989, Maiter et al. 1991b). The observation that hypophysectomy of adult rats blocks the increase in hypothalamic GRF mRNA after dihydrotestosterone treatment (Hasegawa et al. 1992) suggests that any increase in GRF mRNA is a response to altered circulating patterns of $\mathrm{GH}$, implying that androgens do not affect hypothalamic GRF synthesis directly. Most, but not all (Gabriel et al. 1989), studies in rats suggest that oestrogen either suppresses (Fernandez et al. 1992, Senaris et al. 1992, Bennett et al. 1996) or does not affect (Maiter et al. 1991b) GRF synthesis and secretion. In addition to the direct effects of gonadal steroids at the hypothalamus, exposure to steroids during neonatal or prenatal life may have permanent effects on subsequent GRF production. Treatment of male and female rats with testosterone on their day of birth increased and neonatal castration decreased the number of GRF neurones in the hypothalamus, although not the hypothalamic GRF mRNA content (Chowen et al. 1993).

Hypothalamic GRF and GRF $m R N A$ contents are greater in male than in female rats and prepubertal sheep, and are either increased or unchanged by androgens, and decreased or unchanged by oestrogens. Exposure to androgens during neonatal life in rats increases numbers of GRF neurones in the hypothalamus and might therefore increase the capacity for GRF secretion in adulthood.

\section{SRIF synthesis and secretion}

The evidence for sexually dimorphic in vivo secretion of SRIF is also largely indirect. GH secretion by male rats shows an alternating pattern of responsive and refractory periods when GRF is repeatedly administered i.v. at intervals of less than 3-hourly, whilst female rats respond consistently to repeated GRF stimulus (Clark \& Robinson 1985, Painson \& Tannenbaum 1991). This implies that SRIF secretion from the hypothalamus in males is in concentrations sufficient to block the GH secretion response to GRF, except during troughs in SRIF secretion approximately every $3 \mathrm{~h}$, and that SRIF secretion is lower in females. Administration of anti-SRIF serum i.v. in male rats increases plasma interpulse GH concentrations, but does not alter peak GH concentrations (Terry \& Martin 1981, Eikelboom \& Tannenbaum 1983, Painson \& Tannenbaum 1991). In female rats, administration of anti-SRIF serum or lesioning of SRIF-producing regions in the hypothalamus increases both interpulse and peak circulating GH concentrations (Urman et al. 1985, Painson \& Tannenbaum 1991). This implies that SRIF secretion is pulsatile in the male, but relatively constant in the female rat.

Although this indirect evidence suggests that SRIF secretion is sexually dimorphic in rats, most studies have failed to find sex differences in hypothalamic or median eminence SRIF content or in vitro release in the rat (Gross 1980, Critchlow et al. 1986, Ge et al. 1989, Maiter et al. 1990, Leidy et al. 1993). However, Gabriel et al. (1993) reported a greater SRIF content in the median eminence of male rats compared with female rats. In sheep receiving food ad libitum, the median eminence content of SRIF did not differ between sexes (Gatford et al. 1997a). SRIF mRNA expression in the periventricular nucleus, a major site of SRIF synthesis, has been found to be greater in male than in female rats in most studies (Chowen-Breed et al. 1989, Argente et al. 1990, Martinoli et al. 1991, Hasegawa et al. 1992, Chowen et al. 1993), although one study did not observe sex differences (Zorilla et al. 1990). Sex differences have also been observed in the regulation of SRIF secretion in rats. Inhibition of the GH secretion response to GRF and the increase in hypothalamic SRIF content after exposure to increased plasma $\mathrm{GH}$ is greater in males than in females (Clark \& Robinson 1985, Carlsson et al. 1990b, Maiter et al. 1990, Bercu et al. 1991, Painson \& Tannenbaum 1991).

In the rat, castration of males near puberty decreases hypothalamic SRIF mRNA content and androgen treatment of castrate and intact males and intact females increases hypothalamic SRIF mRNA content (Baldino et al. 1988, Werner et al. 1988, Chowen-Breed et al. 1989, Argente et al. 1990, Zorilla et al. 1990, Chowen et al. 1993). Androgen status during the neonatal period also has permanent non-reversible effects on hypothalamic SRIF content. Neonatal castration of male rats reduces, and neonatal testosterone treatment of male or female rats increases, hypothalamic SRIF mRNA content in adulthood (Chowen et al. 1993). In contrast to the effect on GRF-synthesising neurones (Chowen et al. 1993), castration or testosterone treatment during the neonatal period does not alter the number of SRIF-synthesising neurones in the rat (Hasegawa et al. 1992). Although androgens stimulate SRIF mRNA in vivo, one study has reported that in vitro treatment of adult rat hypothalamic cell cultures with testosterone decreased SRIF synthesis and secretion (Fernandez et al. 1992), implying that the stimulatory effects of androgens on hypothalamic SRIF are not due to direct actions of testosterone at the hypothalamus. Consensus has not been reached regarding the effects of oestrogen on SRIF synthesis and secretion. In rats, in vivo oestrogen treatment increases hypothalamic content of SRIF protein and mRNA (Baldino et al. 1988, Werner et al. 1988, Gabriel et al. 1989, Zorilla et al. 1990, Senaris et al. 1992, Bennett et al. 1996) and addition of oestrogen to rat hypothalamic cell cultures inhibits SRIF secretion, but not synthesis (Fernandez et al. 1992). In women, oestrogen treatment reduces the proportion who are refractory to stimulation of GH secretion by GRF, suggesting that SRIF secretion may be decreased by oestrogen (Devesa et al. 1991).

Indirect evidence suggests that SRIF release from the hypothalamus is pulsatile in male rats, but relatively constant in female 


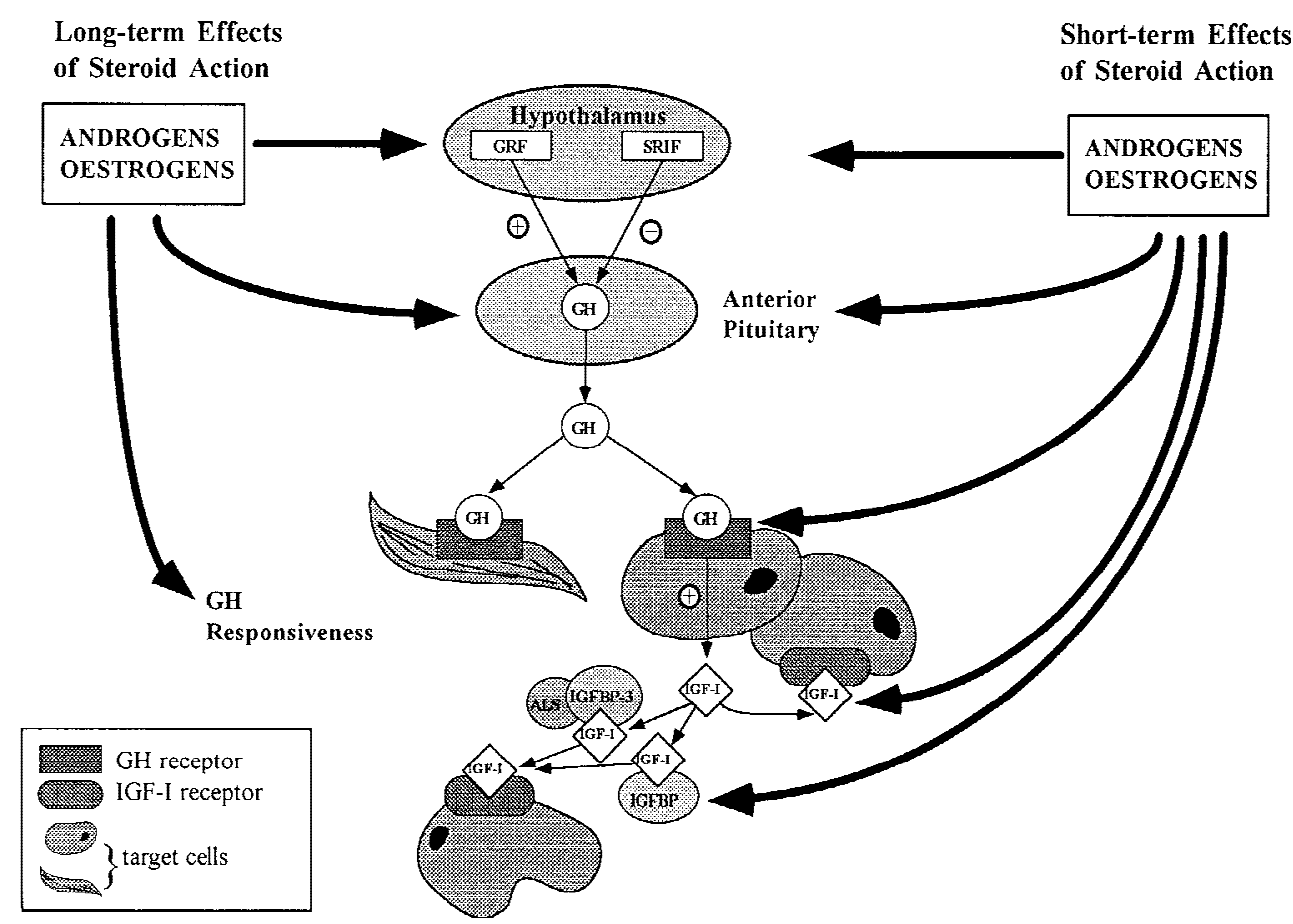

Figure 2 Actions of steroid hormones on the somatotrophic axis. IGF-I, insulin-like growth factor-l; IGFBP, IGF-binding protein; ALS, acid-labile subunit; +, stimulatory; - , inhibitory.

rats, which may cause the low interpulse GH concentrations observed in male rats. Consistent with this, SRIF $m R N A$ expression in the periventricular nucleus is usually greater in male than in female rats. Hypothalamic SRIF and SRIF $m R N A$ content in adult rats are increased by androgen treatment or prenatal androgen exposure, but the effects of oestrogens on SRIF are less clear.

\section{Conclusions}

Although aspects of the somatotrophic axis such as temporal profiles of circulating GH differ between males and females in all species investigated to date, the patterns of differences and the developmental stage at which sex differences become apparent are not the same for all species. In most species, sex differences in circulating IGF-I and IGF-binding protein-3 correspond to sex differences in the temporal profile and mean circulating concentrations of GH. In non-primate species, mean circulating GH, IGF-I and IGF-binding protein-3 concentrations are generally greater in males than in females and probably cause faster growth rates in males than in females. In contrast, mean circulating concentrations of $\mathrm{GH}$ and total IGF-I in primates are greater in females than in males, implying either that the somatotrophic axis is less important for postnatal growth regulation in primates than it is in other species, or that growth is related to other aspects of the axis, for example free hormone concentrations, rather than total concentrations. For example, in girls treated for central precocious puberty, IGF-I remains stable, but circulating IGF-binding protein-3 increases and growth rate decreases (Juul et al. 1995a).

Sex differences in the somatotrophic axis probably originate at the anterior pituitary, and possibly the hypothalamus. There is good in vivo and in vitro evidence that gonadal steroids affect pituitary GH responsiveness to GRF and SRIF. Although indirect evidence suggests that GRF and SRIF secretion may differ between sexes in the pituitary-intact animal, it has not yet been possible to characterise portal plasma concentrations of GRF and SRIF in animals in which GH secretion is undisturbed. Development of a model in which this is possible is necessary to separate the direct effects of gonadal steroids at the pituitary and hypothalamus. In addition to direct effects at the pituitary and hypothalamus, gonadal steroids may act during development to modify subsequent secretion of GRF or SRIF, or both, for example by affecting numbers of hormone-secreting neurones. Figure 2 summarises the actions of steroid hormones on the somatotrophic axis.

The actions of gonadal steroids may account for sex differences in the somatotrophic axis before, during or after puberty, depending on species, and may include changes in hormone receptor numbers or function in addition to changes in the secretion of hypothalamic or pituitary 
hormones, or both, and altered responsiveness of target tissues to somatotrophic axis hormones. Thus the somatotrophic axis may be a major pathway through which steroids act to produce sex differences in growth and body composition.

\section{References}

Aguilar E \& Lopez F 1988 GH response to GRF(1-29) $\mathrm{NH}_{2}$ in female rats treated neonatally with estradiol benzoate or testosterone propionate. Journal of Steroid Biochemistry 29 727-729.

Albertsson-Wikland K \& Rosberg S 1988 Analyses of 24-h growth hormone profiles in children: relation to growth. Journal of Clinical Endocrinology and Metabolism 67 493-500.

Aldrich SL, Berger LL, Kesler DJ, Nash TG \& McCusker RH Jr 1996 Effects of prenatal androgenization and postnatal steroid treatment on growth hormone, insulin-like growth factor I and II, insulin, thyroxine, and triiodothyronine concentrations in beef heifers. Journal of Animal Science 74 420-428.

Amit T, Hochberg Z, Waters MJ \& Barkey RJ 1992 Growth hormone- and prolactin-binding proteins in mammalian serum. Endocrinology 131 1793-1803.

Argente J, Chowen-Breed JA, Steiner RA \& Clifton DK 1990 Somatostatin messenger mRNA is increased by testosterone through activation of androgen receptors and not by aromatization to estradiol. Neuroendocrinology 52 342-349.

Argente J, Chowen JA, Zeitler P, Clifton DK \& Steiner RA 1991 Sexual dimorphism of growth hormone-releasing hormone and somatostatin gene expression in the hypothalamus of the rat during development. Endocrinology 128 2369-2375.

Argetsinger LS \& Carter-Su C 1996 Mechanism of signalling by growth hormone receptor. Physiological Reviews 76 1089-1107.

Arsenijevic I, Rivest RW, Eshkol A, Sizonenko PC \& Aubert ML 1987 Plasma growth hormone $(\mathrm{GH})$ response to intravenous GH-releasing factor (GRF) in adult rats: evidence for transient pituitary desensitization after GRF stimulation. Endocrinology 121 1487-1496.

Bacon WL, Nestor KE, Emmerson DA, Vasilatos-Younken R \& Long DW 1993 Circulating IGF-I in plasma of growing male and female turkeys of medium and heavy weight lines. Domestic Animal Endocrinology 10 267-277.

Badger TM, Millard WJ, Owens SM, LaRovere J \& O'Sullivan D 1991 Effects of gonadal steroids on clearance of growth hormone at steady state in the rat. Endocrinology 128 1065-1072.

Baldino F Jr, Fitzpatrick-McElligott S, O’Kane TM \& Gozes I 1988 Hormonal regulation of somatostatin messenger RNA. Synapse 2 317-325.

Ballard FJ, Johnson RJ, Owens PC, Francis GL, Upton FM, McMurtry JP \& Wallace JC 1990 Chicken insulin-like growth factor-I: amino acid sequence, radioimmunoassay, and plasma levels between strains and during growth. General and Comparative Endocrinology 79 459-468.

Bassett NS \& Gluckman PD 1986 Pulsatile growth hormone secretion in the ovine fetus and neonatal lamb. Journal of Endocrinology 109 307-312.

Batson JM, Kreig RJ Jr, Martha PM Jr \& Evans WS 1989 Growth hormone $(\mathrm{GH})$ response to GH-releasing hormone by perifused pituitary cells from male, female, and testicular feminized rats. Endocrinology 124 444-448.

Bauer M \& Parvizi N 1996 Pulsatile and diurnal secretion of GH and IGF-I in the chronically catheterized pig fetus. Journal of Endocrinology 149 125-133.

Baumann G 1994 Growth hormone-binding proteins: state of the art. Journal of Endocrinology 141 1-6.

Baumbach WR \& Bingham B 1995 One class of growth hormone $(\mathrm{GH})$ receptor and binding protein messenger ribonucleic acid in rat liver, $\mathrm{GHR}_{1}$, is sexually dimorphic and regulated by $\mathrm{GH}$. Endocrinology 136 749-760.

Baumbach WR, Horner DL \& Logan JS 1993 The growth hormone-binding protein in rat serum is an alternatively spliced form of the rat growth hormone receptor. Genes and Development 3 1199-1205.

Benito P, Avila L, Corpas MS, Jimenez JA, Cacicedo L \& SanchezFranco F 1991 Sex differences in growth hormone response to growth hormone-releasing hormone. Journal of Endocrinological Investigation 14 265-268.

Bennett PA, Levy A, Carmignac DF, Robinson ICAF \& Lightman SL 1996 Differential regulation of the growth hormone receptor gene: effects of dexamethasone and estradiol. Endocrinology 137 3891-3896.

Bercu BB, Weideman CA \& Walker RF 1991 Sex differences in growth hormone $(\mathrm{GH})$ secretion by rats administered GH-releasing hexapeptide. Endocrinology 129 2592-2598.

Bertherat J, Bluet-Pajot MT \& Epelbaum J 1995 Neuroendocrine regulation of growth hormone. European Journal of Endocrinology 132 $12-24$.

Bethea CL 1991 Estrogen action on growth hormone in pituitary cell cultures from adult and juvenile macaques. Endocrinology 129 2110-2118.

Bick T, Amit T, Barkey RJ, Hertz P, Youdim M \& Hochberg Z 1990 The interrelationship of growth hormone $(\mathrm{GH})$, liver membrane $\mathrm{GH}$ receptor, serum GH-binding activity, and insulin-like growth factor I in the male rat. Endocrinology 126 1914-1920.

Bick T, Hochberg Z, Amit T, Isaksson OGP \& Jansson J-O 1992 Roles of pulsatility and continuity of growth hormone $(\mathrm{GH})$ administration in the regulation of hepatic GH-receptors, and circulating GH-binding protein and insulin-like growth factor-I. Endocrinology 131 423-429.

Bingham B, Oldham ER \& Baumbach WR 1994 Regulation of growth hormone receptor and binding protein expression in domestic species. Proceedings of the Society for Experimental Biology and Medicine 206 195-199.

Bishop MD, Simen RCM, Simmen F \& Davis ME 1989 The relationship of insulin-like growth factor-I with post-weaning performance in Angus beef cattle. Journal of Animal Science 6 2872-2880.

Blair HT, McCutcheon SN, Mackenzie DDS, Gluckman PD \& Ormsby JE 1987 Variation in plasma concentration of insulin-like growth factor-1 and its covariation with liveweight in mice. Australian Journal of Biological Sciences 40 287-293.

Borski RJ, Tsai W, DeMott-Friberg R \& Barkan AL 1996 Regulation of somatic growth and the somatotropic axis by gonadal steroids: primary effect on insulin-like growth factor I gene expression and secretion. Endocrinology 137 3253-3259.

Breier BH, Gluckman PD \& Bass JJ 1988 Influence of nutritional status and oestradiol-17 $\beta$ on plasma growth hormone, insulin-like growth factors-I and -II and the response to exogenous growth hormone in young steers. Journal of Endocrinology 118 243-250.

Brody S, Hogan AG, Kempster HL, Ragsdale AC \& Trowbridge EA 1926 Growth and devlopment, with special reference to domestic animals. I. Quantitative data. 1. Weight growth and linear growth. University of Missouri Agricultural Experimental Station Research Bulletin No. 96.

Brozek J 1967 Interaction of human and animal research on body composition. In Body Composition in Animals and Man, pp 3-15. Proceedings of a Symposium, 4-6 May 1967, University of Missouri, Columbia. Washington: National Academy of Sciences.

Buonomo FC \& Klindt J 1993 Ontogeny of growth hormone (GH), insulin-like growth factors (IGF-I and IGF-II) and IGF binding protein-2 (IGFBP-2) in genetically lean and obese swine. Domestic Animal Endocrinology 10 257-265. 
Burman P, Johansson AG, Seigbahn A, Vessby B \& Karlsson FA 1997 Growth hormone $(\mathrm{GH})$-deficient men are more responsive to $\mathrm{GH}$ replacement therapy than women. Journal of Clinical Endocrinology and Metabolism 82 550-555.

Butenandt O, Eder R, Wohlfarth K, Bidlingmaier F \& Knorr D 1976 Mean 24-hour growth hormone and testosterone concentrations in relation to pubertal growth spurt in boys with normal or delayed puberty. European Journal of Pediatrics 122 85-92.

Campbell RG \& Taverner MR 1988 Genotype and sex effects on the relationship between energy intake and protein deposition in growing pigs. Journal of Animal Science 66 676-686.

Campbell RG, Johnson RJ, King RH \& Taverner MR 1990 Effects of gender and geneotype on the response of growing pigs to exogenous administration of porcine growth hormone. Journal of Animal Science 68 2674-2681.

Carlson HE, Jacobs LS \& Daughaday WH 1973 Growth hormone, thyrotropin and prolactin responses to thyrotropin-releasing hormone following diethylstilbestrol pretreatment. Journal of Clinical Endocrinology and Metabolism 37 488-490.

Carlsson B, Billig H, Rymo L \& Isaksson OGP 1990a Expression of the growth hormone-binding protein messenger RNA in the liver and extrahepatic tissues in the rat: co-expression with the growth hormone receptor. Molecular and Cellular Endocrinology 73 R1-R6.

Carlsson LMS, Clark RG \& Robinson ICAF $1990 b$ Sex difference in growth hormone feedback in the rat. Journal of Endocrinology 126 $27-35$.

Carmignac DF, Wells T, Carlsson LM, Clark RG \& Robinson IC 1992 Growth hormone (GH)-binding protein in normal and GH-deficient dwarf rats. Journal of Endocrinology 135 447-457.

Carmignac DF, Gabriellson BG \& Robinson ICAF 1993a Growth hormone binding protein in the rat: effects of gonadal steroids. Endocrinology 133 2445-2452.

Carmignac DF, Robinson ICAF, Enberg B \& Norstedt G 19936 Growth hormone receptor regulation in growth hormone-deficient rats. Journal of Endocrinology 138 267-274.

Carter-Su C, Schrawtz J \& Smit LS 1996 Molecular mechanism of growth hormone action. Annual Review of Physiology 58 187-207.

Chowen JA, Argente J, Gonzalez-Parra S \& Garcia-Segura LM 1993 Differential effects of the neonatal and adult sex steroid environments on the organization and activation of hypothalamic growth hormone-releasing hormone and somatostatin neurons. Endocrinology 133 2792-2809.

Chowen JA, Garcia-Segura LM, Gonzalez-Parra S \& Argente J 1996 Sex steroid effects on the development and functioning of the growth hormone axis. Cellular and Molecular Neurobiology 16 297-310.

Chowen-Breed JA, Steiner RA \& Clifton DK 1989 Sexual dimorphism and testosterone-dependent regulation of somatostatin gene expression in the periventricular nucleus of the rat brain. Endocrinology 125 357-362.

Clark RG \& Robinson ICAF 1985 Growth hormone responses to multiple injections of a fragment of human growth hormonereleasing hormone in conscious male and female rats. Journal of Endocrinology 106 281-289.

Clark RG, Carlsson LMS \& Robinson ICAF 1987 Growth hormone secretory profiles in conscious female rats. Journal of Endocrinology 114 399-407.

Clemmons DR 1996 Insulin-like growth factor binding proteins and their role in controlling IGF actions. Cytokine and Growth Factor Reviews 8 45-62.

Cohick WS \& Clemmons DR 1993 The insulin-like growth factors. Annual Review of Physiology 55 131-153.

Copeland KC, Johnson DM, Kuehl TJ \& Castracane VD 1984 Estrogen stimulates growth hormone and somatomedin-C in castrate and intact female baboons. Journal of Clinical Endocrinology and Metabolism 58 698-703.
Copeland KC, Eichberg JW, Parker CR Jr \& Bartke A 1985 Puberty in the chimpanzee: somatomedin-C and its relationship to somatic growth and steroid hormone concentrations. Journal of Clinical Endocrinology and Metabolism 60 1154-1160.

Costin G, Kaufman FR \& Brasel JA 1989 Growth hormone secretory dynamics in subjects with normal stature. Journal of Pediatrics 115 537-544.

Coxam V, Davicco M-J, Durand D, Bauchart D, Opmeer F \& Barlet J-P 1990 Steroid hormone may modulate hepatic somatomedin C production in newborn calves. Biology of the Neonate 58 16-23.

Craft WH \& Underwood LE 1984 Effect of androgens on plasma somatomedin-C/insulin-like growth factor I responses to growth hormone. Clinical Endocrinology 20 549-554.

Crawford BA \& Handelsman DJ 1996 Androgens regulate circulating levels of insulin-like growth factor (IGF)-I and IGF binding protein-3 during puberty in male baboons. Journal of Clinical Endocrinology and Metabolism 81 65-72.

Crawford BA, Dobbie P, Bass JJ, Lewitt MS, Baxter RC \& Handelsman DJ 1994 Growth hormone (GH) regulation of circulating insulin-like growth factor-I levels during sexual maturation of the dwarf $(d w / d w)$ male rat. Journal of Endocrinology 141 393-401.

Critchlow V, Dyke A \& Kaler LW 1986 Release of growth hormone, prolactin and somatostatin during perifusion of anterior pituitary and preoptic-medial basal hypothalamus from male and female rats. Brain Research 398 347-353.

Cronin MJ \& Rogol AD 1984 Sex differences in the cyclic adenosine $3^{\prime}, 5^{\prime}$-monophosphate and growth hormone response to growth hormone-releasing factor in vitro. Biology of Reproduction $\mathbf{3 1}$ 984-988.

Davis ME, Bishop MD, Park NH \& Simmen RC 1995 Divergent selection for blood serum insulin-like growth factor I concentration in beef cattle: I. Nongenetic effects. Journal of Animal Science $\mathbf{7 3}$ 1927-1932.

Davis SL, Ohlson DL, Klindt J \& Anfinson MS 1977 Episodic growth hormone secretory patterns in sheep: relationship to gonadal steroid hormones. American Journal of Physiology 233 E519-E523.

Davis SL, Graf M, Morrison CA, Hall TR \& Swift PJ 1992 Identification and partial purification of serum growth hormone binding protein in domestic animal species. Journal of Animal Science $70773-780$.

Dawson-Hughes B, Stern D, Goldman J \& Reichlin S 1986 Regulation of growth hormone and somatomedin-C secretion in postmenopausal women: effect of physiological estrogen replacement. Journal of Clinical Endocrinology and Metabolism $\mathbf{6 3}$ 424-432.

Decuypere E, Leenstra FR, Buyse J, Huybrechts LM, Buonomo FC \& Berghman LR 1993 Plasma levels of growth hormone and insulin-like growth factor-I and -II from 2 to 6 weeks of age in meat-type chickens selected for 6-week body weight or for feed conversion and reared under high or normal environmental temperature conditions. Reproduction, Nutrition and Development 33 361-372.

De Gennaro Colonna V, Cocchi D, Lima L, Maggi A \& Muller EE 1991 Testosterone and GHRH gene expression in adult and old rats. Peptides 12 309-312.

DeHaan KC, Berger LL, Kesler DJ, McKeith FK, Faulkner DB \& Cmarik GF 1988 Effect of prenatal androgenization on growth performance and carcass characteristics of steers and heifers. Journal of Animal Science 66 1864-1870.

DeHaan KC, Berger LL, Bechtel PJ, Kesler DJ, McKeith FK \& Thomas DL 1990a Effect of prenatal testosterone treatment on nitrogen utilization and endocrine status of ewe lambs. Journal of Animal Science 68 4100-4108.

DeHaan KC, Berger LL, Kesler DJ, McKeith FK, Faulkner DB, Cmarik GF \& Favero RJ 1990 b Effects of prenatal testosterone 
treatment and postnatal steroid implantation on growth performance and carcass traits of heifers and steers. Journal of Animal Science $\mathbf{6 8}$ 2198-2207.

Devesa J, Lois N, Arce V, Diaz MJ, Lima L \& Tresguerres JAF 1991 The role of sexual steroids in the modulation of growth hormone (GH) secretion in humans. Journal of Steroid Biochemistry and Molecular Biology 40 165-173.

Devesa J, Lima L \& Tresguerres JAF 1992 Neuroendocrine control of growth hormone secretion in humans. Trends in Endocrinology and Metabolism 3 175-183.

Domene HM, Marin G, Sztein J, Yu YM, Baron J \& Cassorla FG 1994 Estradiol inhibits growth hormone receptor gene expression in rabbit liver. Molecular and Cellular Endocrinology 103 81-87.

Dubreuil P, Pelletier G, Peticlerc D, Lapierre H, Couture Y, Brazeau P, Gaudreau P \& Morriset J 1987 Influence of age and sex on basal secretion of growth hormone $(\mathrm{GH})$ and on $\mathrm{GH}$-induced release by porcine $\mathrm{GH}$-releasing factor $\mathrm{pGRF}\left(1-29 \mathrm{NH}_{2}\right)$ in growing pigs. Domestic Animal Endocrinology 5 157-164.

Dubreuil P, Pelletier G, Couture Y, Lapierre H, Petitclerc D, Morriset J, Gaudreau P \& Brazeau P 1989 Castration and testosterone effects on endogenous and somatocrinin-induced growth hormone release in intact and castrated male pigs. Domestic Animal Endocrinology 6 15-24.

Edén S 1979 Age- and sex-related differences in episodic growth hormone secretion in the rat. Endocrinology 105 555-560.

Eikelboom R \& Tannenbaum GS 1983 Effects of obesity-inducing ventromedial hypothalamic lesions on pulsatile growth hormone and insulin secretion: evidence for the existence of a growth hormonereleasing factor. Endocrinology 112 212-219.

Erfurth EM, Hagmar LE, Saaf M \& Hall K 1996 Serum levels of insulin-like growth factor I and insulin-like growth factor binding protein 1 correlate with serum free testosterone and sex hormone binding globulin levels in healthy young and middle-aged men. Clinical Endocrinology 44 659-664.

Evans WS, Krieg RJ, Limber ER, Kaiser DL \& Thorner MO 1985 Effects of in vivo gonadal hormone environment on in vitro hGRF-40-stimulated GH release. American Journal of Physiology 249 E276-E280.

Faria ACS, Bekenstein LW, Booth RA Jr, Vaccaro VA, Asplin CM, Veldhuis JD, Thorner MO \& Evans WS 1992 Pulsatile growth hormone release in normal women during the menstrual cycle. Clinical Endocrinology 36 591-596.

Fernandez G, Sanchez-Franco F, de los Frailes MT, Tolon RM, Lorenzo MJ, Lopez J \& Cacicedo L 1992 Regulation of somatostatin and growth hormone-releasing factor by gonadal steroids in fetal rat hypothalamic cells in culture. Regulatory Peptides 42 135-144.

Fishman A, Hertz P \& Hochberg Z 1993 Ontogenesis of the sexual dimorphism of growth hormone secretion by perifused rat hemipituitaries. Neuroendocrinology 57 782-788.

Fletcher TP, Thomas GB \& Clarke IJ 1996 Growth hormonereleasing hormone $(\mathrm{GHRH})$ and somatostatin (SRIF) concentrations in the hypophysial portal blood of conscious sheep during the infusion of growth hormone-releasing peptide-6 (GHRP-6). Domestic Animal Endocrinology 13 251-258.

Fourie PD, Kirton AH \& Jury KE 1970 Growth and development of sheep. II. Effect of breed and sex on the growth and carcass composition of the Southdown and Romney and their cross. New Zealand Journal of Agricultural Research 13 753-770.

Frohman LA, Downs TR, Clarke IJ \& Thomas GB 1990 Measurement of growth hormone-releasing hormone and somatostatin in hypothalamic-portal plasma of unanesthetized sheep. Journal of Clinical Investigation 86 17-24.

Fukata J \& Martin JB 1986 Influence of sex steroid hormones on rat growth hormone-releasing factor and somatostatin in dispersed pituitary cells. Endocrinology 119 2256-2261.
Funston RN, Moss GE \& Roberts AJ 1995 Insulin-like growth factor-I (IGF-I) and IGF-binding proteins in bovine sera and pituitaries at different stages of the estrous cycle. Endocrinology 136 $62-68$.

Gabriel SM, Millard WJ, Koenig JI, Badger TM, Russell WE, Maiter DM \& Martin JB 1989 Sexual and developmental differences in peptides regulating growth hormone secretion in the rat. Neuroendocrinology $\mathbf{5 0}$ 299-307.

Gabriel SM, Roncancio JR \& Ruiz NS 1992 Growth hormone pulsatility and the endocrine milieu during sexual maturation in male and female rats. Neuroendocrinology 56 619-628.

Gabriel SM, Hunnicut EH, Millard WJ, Badger TM \& Nathanson JA 1993 Influence of in vivo reproductive endocrine state on growth hormone-releasing factor stimulated adenylate cyclase activity in anterior pituitary fragments. Neuroendocrinology 57 63-69.

Gabrielsson BG, Carmignac DF, Flavell DM \& Robinson ICAF 1995 Steroid regulation of growth hormone $(\mathrm{GH})$ receptor and $\mathrm{GH}-$ binding protein messenger ribonucleic acids in the rat. Endocrinology 136 209-217.

Gatford KL, Fletcher TP, Clarke IJ, Owens PC, Quinn KJ, Walton PE, Grant PA, Hosking BJ, Egan AR \& Ponnampalam EN 1996 Sexual dimorphism of circulating somatotropin, insulin-like growth factor I and II, insulin-like growth factor binding proteins, and insulin: relationships to growth rate and carcass characteristics in growing lambs. Journal of Animal Science 74 1314-1325.

Gatford KL, Fletcher TP, Rao A, Egan AR, Hosking BJ \& Clarke IJ 1997a Growth hormone (GH), GH-releasing factor, and somatostatin in the growing lamb: sex differences and mechanisms for sex differences. Journal of Endocrinology 152 19-27.

Gatford KL, Quinn KJ, Walton PE, Grant PA, Hosking BJ, Egan AR \& Owens PC $1997 b$ Ontogenic and nutritional changes in circulating insulin-like growth factor (IGF)-I, IGF-II, and IGF-binding proteins in growing ewe and ram lambs. Journal of Endocrinology 155 47-54.

Ge F, Tsagarakis S, Rees LH, Besser GM \& Grossman A 1989 Relationship between growth hormone-releasing hormone and somatostatin in the rat: effects of age and sex on content and in vitro release from hypothalamic explants. Journal of Endocrinology 123 $53-58$.

Gelato MC, Pescovitz OH, Cassorla F, Loriaux DL \& Merriam GR 1984 Dose-response relationships for the effects of growth hormone-releasing factor-(1-44)- $\mathrm{NH}_{2}$ in young adult men and women. Journal of Clinical Endocrinology and Metabolism 59 197-201.

Gevers EF, Wit JM \& Robinson ICAF 1996 Growth, growth hormone $(\mathrm{GH})$-binding protein, and $\mathrm{GH}$ receptors are differentially regulated by peak and trough components of the GH secretory pattern in the rat. Endocrinology 137 1013-1018.

Goffin V, Shiverick KT, Kelly PA \& Martial JA 1996 Sequencefunction relationships within the expanding family of prolactin, growth hormone, placental lactogen, and related proteins in mammals. Endocrine Reviews 17 385-410.

Gopinath R \& Kitts WD 1984 Growth hormone secretion and clearance rates in growing beef steers implanted with estrogenic anabolic compounds. Growth 48 499-514.

Gross DS 1980 Role of somatostatin in the modulation of hypophysial growth hormone production by gonadal steroids. American Journal of Anatomy 158 507-519.

Hannon K, Gronowski A \& Trenkle A 1991 Relationship of liver and skeletal muscle IGF-1 mRNA to plasma GH profile, production of IGF-1 by liver, plasma IGF-1 concentrations, and growth rates of cattle. Proceedings of the Society for Experimental Biology and Medicine 196 155-163.

Harrela M, Koistinen H, Kaprio J, Lehtovirta M, Tuomilehto J, Eriksson J, Toivanen L, Koskenvuo M, Leinonen P, Koistenen R \& Seppälä M 1996 Genetic and environmental components of interindividual variation in circulating levels of IGF-I, IGF-II, IGFBP-1 and IGFBP-3. Journal of Clinical Investigation 98 2612-2615. 
Hartman ML, Veldhuis JD \& Thorner MO 1993 Normal control of growth hormone secretion. Hormone Research 40 37-47.

Hasegawa O, Sugihara H, Minami S \& Wakabayashi I 1992 Masculinization of growth hormone $(\mathrm{GH})$ secretory pattern by dihydrotestosterone is associated with augmentation of hypothalamic somatostatin and GH-releasing hormone mRNA levels in ovariectomized adult rats. Peptides 13 475-481.

Hassan HA, Merkel RA, Enright WJ \& Tucker HA 1992 Androgens modulate growth hormone-releasing factor-induced GH release from bovine anterior pituitary cells in static culture. Domestic Animal Endocrinology 9 209-218.

Herington AC, Ymer SI, Stevenson JL \& Roupas P 1994 Growth hormone receptor/binding protein: physiology and function. Proceedings of the Society for Experimental Biology and Medicine 206 238-242.

Hertz P, Silbermann M, Even L \& Hochberg Z 1989 Effects of sex steroids on the response of cultured rat pituitary cells to growth hormone-releasing hormone and somatostatin. Endocrinology 125 $581-585$.

Ho KK, Valiontis E, Waters MJ \& Rajkovic IA 1993 Regulation of growth hormone binding protein in man: comparison of gel chromatography and immunoprecipitation methods. Journal of Clinical Endocrinology and Metabolism 76 302-308.

Ho KK, O'Sullivan AJ, Weissberger AJ \& Kelly JJ 1996 Sex steroid regulation of growth hormone secretion and action. Hormone Research 45 67-73.

Ho KY, Leong DA, Sinha YN, Johnson ML, Evans WS \& Thorner MO 1986 Sex-related differences in GH secretion in rat using reverse hemolytic plaque assay. American Journal of Physiology 250 E650-E654.

Ho KY, Evans WS, Blizzard RM, Veldhuis JD, Merriam GR, Samojlik E, Furlanetto R, Rogol AD, Kaiser DL \& Thorner MO 1987 Effects of sex and age on the 24-hour profile of growth hormone secretion in man: importance of endogenous estradiol concentrations. Journal of Clinical Endocrinology and Metabolism 64 51-58.

Hoeffler JP \& Frawley LS 1986 Capacity of individual somatotrophs to release growth hormone $(\mathrm{GH})$ varies according to sex: analysis by reverse hemolytic plaque assay. Endocrinology 119 1037-1041.

Holl RW, Schwartz U, Schauwecker P, Benz R, Veldhuis JD \& Heinze E 1993 Diurnal variation in the elimination rate of human growth hormone $(\mathrm{GH})$ : the half-life of serum $\mathrm{GH}$ is prolonged in the evening, and affected by the source of the hormone, as well as by body size and serum estradiol. Journal of Clinical Endocrinology and Metabolism 77 216-220.

Hu Z, Friberg RD \& Barkan AL 1993 Ontogeny of GH mRNA and $\mathrm{GH}$ secretion in male and female rats: regulation by GH-releasing hormone. American Journal of Physiology 265 E236-E242.

Illig R \& Prader A 1970 Effect of testosterone on growth hormone secretion in patients with anorchia and delayed puberty. Journal of Clinical Endocrinology 30 615-618.

Ip TP, Hoffman DM, O’Sullivan AJ, Leung KC \& Ho KK 1995 Do androgens regulate growth hormone-binding protein in adult man? Journal of Clinical Endocrinology and Metabolism 80 1278-1282.

Iranmanesh A, Lizarralde G \& Veldhuis JD 1991 Age and relative adiposity are specific negative determinants of the frequency and amplitude of growth hormone $(\mathrm{GH})$ secretory bursts and the half-life of GH in healthy men. Journal of Clinical Endocrinology and Metabolism 73 1081-1088.

Jansson J-O \& Frohman LA 1987 Differential effects of neonatal and adult androgen exposure on the growth hormone secretory pattern in male rats. Endocrinology 120 1551-1557.

Jansson J-O, Carlsson L \& Seeman H 1983 Estradiol - but not testosterone - stimulates the secretion of growth hormone in rats with the pituitary gland autotransplanted to the kidney capsule. Acta Endocrinologica 103 (Suppl 256) 212.
Jansson J-O, Ekberg S, Isaksson OGP \& Edén S 1984 Influence of gonadal steroids on age- and sex-related secretory patterns of growth hormone in the rat. Endocrinology 114 1287-1294.

Jansson J-O, Edén S, \& Isaksson O 1985 Sexual dimorphism in the control of growth hormone secretion. Endocrine Reviews 6 128-150.

Jenkins TG, Ford JJ \& Klindt J 1988 Postweaning growth, feed efficiency and chemical composition of sheep as affected by prenata and postnatal testosterone. Journal of Animal Science 66 1179-1185.

Johannsson G, Bjarnason R, Bramnert M, Carlsson LMS, Degerblad M, Manhem P, Rosén T, Thorén M \& Bengtsson B-A 1996 The individual responsiveness to growth hormone $(\mathrm{GH})$ treatment in GH-deficient adults is dependent on the level of GH-binding protein, body mass index, age, and gender. Journal of Clinical Endocrinology and Metabolism 81 1575-1581.

Johnson RJ, McMurtry JP \& Ballard FJ 1989 Ontogeny and secretory patterns of plasma insulin-like growth factor-I concentrations in meat-type chickens. Journal of Endocrinology 124 81-87.

Juul A, Bang P, Hertel NT, Main K, Dalgaard P, Jorgensen K, Müller J, Hall K \& Skakkebæk NE 1994 Serum insulin-like growth factor-I in 1030 healthy children, adolescents, and adults: relation to age, sex, stage of puberty, testicular size, and body mass index. Journal of Clinical Endocrinology and Metabolism 78 744-752.

Juul A, Scheike T, Nielsen CT, Krabbe S, Müller J \& Skakkebæk NE 1995a Serum insulin-like growth factor I (IGF-I) and IGF-binding protein-3 levels are increased in central precocious puberty: effects of two different treatment regimens with gonadotropin-releasing hormone agonists, without or in combination with an antiandrogen (cyproterone acetate). Journal of Clinical Endocrinology and Metabolism 80 3059-3067.

Juul A, Dalgaard P, Blum WF, Bang P, Hall K, Michaelsen KF, Müller J \& Skakkebæk NE 1995 b Serum levels of insulin-like growth factor (IGF)-binding protein-3 (IGFBP-3) in healthy infants, children, and adolescents: the relation to IGF-I, IGF-II, IGFBP-1, IGFBP-2, age, sex, body mass index, and pubertal maturation. Journal of Clinical Endocrinology and Metabolism 80 2534-2542.

Kalu DN, Arjmandi BH, Liu CC, Salih MA \& Birnbaum RS 1994 Effects of ovariectomy and estrogen on the serum levels of insulin-like growth factor-I and insulin-like growth factor binding protein-3. Bone Mineralization 25 135-148.

Kelly JJ, Rajkovic IA, O’Sullivan AJ, Sernia C \& Ho KK 1993 Effects of different oral oestrogen formulations on insulin-like growth factor-I, growth hormone and growth hormone binding protein in post-menopausal women. Clinical Endocrinology 39 561-567.

Kelly PA, Posner BI, Tsushima T \& Freisen HG 1974 Studies of insulin, growth hormone and prolactin binding: ontogenesis, effects of sex and pregnancy. Endocrinology 95 532-539.

Kerrigan JR \& Rogol AD 1992 The impact of gonadal steroid action on growth hormone secretion during childhood and adolescence. Endocrine Reviews 13 281-298.

Kerrigan JR, Martha P Jr, Kreig RJ Jr, Rogol AD \& Evans WS 1989 Somatostatin inhibition of growth hormone secretion by somatotropes from male, female, and androgen receptor-deficient rats: evidence for differing sensitivities. Endocrinology 125 3078-3083.

Klein NA, Battaglia DE, Miller PB \& Soules MR 1996 Circulating levels of growth hormone, insulin-like growth factor-I and growth hormone binding protein in normal women of advanced reproductive age. Clinical Endocrinology 44 285-292.

Klindt J, Jenkins TG \& Ford JJ 1987 Prenatal androgen exposure and growth and secretion of growth hormone and prolactin in ewes postweaning. Proceedings of the Society for Experimental Biology and Medicine 185 201-205.

Kobayashi Y, Murata A, Yasuda T, Minagawa M, Wataki K, Ohnishi H \& Niimi H 1994 Suppression of sex steroids by a gonadotrophinreleasing hormone agonist increases serum growth hormone-binding protein activity in girls with central idiopathic precocious puberty. Clinical Endocrinology 40 351-355. 
Kraetzl WD, Schams D \& Brem G 1994 Secretory patterns of porcine growth hormone and insulin-like growth-factor-I in growing pigs. Journal of Animal Physiology and Animal Nutrition 71 1-14.

Lamberson WR, Safranski TJ, Bates RO, Keisler DH \& Matteri RL 1995 Relationships of serum insulin-like growth factor I concentration to growth, composition, and reproductive traits of swine. Journal of Animal Science 73 3241-3245.

Lang I, Schernthaner G, Pietschmann P, Kurz R, Stephenson JM \& Templ H 1987 Effects of sex and age on growth hormone response to growth hormone-releasing hormone in healthy individuals. Journal of Clinical Endocrinology and Metabolism 65 535-540.

Laron Z 1993 Disorders of growth hormone resistance in childhood. Current Opinions in Pediatrics 5 474-480.

Lee CY, Bazer FW \& Simmen FA 1993 Expression of components of the insulin-like growth factor system in pig mammary glands and serum during pregnancy and pseudopregnancy: effects of oestrogen. Journal of Endocrinology 137 473-483.

Leidy JW Jr, Romano TM \& Millard WJ 1993 Developmental and sex-related changes of the growth hormone axis in lean and obese Zucker rats. Neuroendocrinology 57 213-223.

Leung DW, Spencer SA, Cachianes G, Hammonds RG, Collins C, Henzel WJ, Barnard R, Waters MJ \& Wood WI 1987 Growth hormone receptor and serum binding protein: purification, cloning and expression. Nature 330 537-543.

Leung K-C, Millard W, Peters E, Markus I, Baumbach W, Barnard R \& Ho K 1994 Measurement of GH binding protein in the rat by a ligand immunofunctional assay. Proceedings of the Endocrine Society of Australia 37118.

Lewis UJ 1992 Growth hormone. What is it and what does it do? Trends in Endocrinology and Metabolism 3 117-121.

Lewitt MS, Saunders H, Phyual JL \& Baxter RC 1994 Regulation of insulin-like growth factor-binding protein-1 in rat serum. Diabetes 43 232-239.

Lima L, Arce V, Lois N, Fraga C, Lechuga MJ, Tresguerres JAF \& Devesa J 1989 Growth hormone (GH) responsiveness to GHRH in normal adults is not affected by short-term gonadal blockade. Acta Endocrinologica 120 31-36.

Liu L, Merriam GR \& Sherins RJ 1987 Chronic sex steroid exposure increases mean plasma growth hormone concentration and pulse amplitude in men with isolated hypogonadotropic hypogonadism. Journal of Clinical Endocrinology and Metabolism 64 651-656.

Louveau I, Bonneau M \& Slater DN 1991 Age-related changes in plasma porcine growth hormone $(\mathrm{GH})$ profiles and insulin-like growth factor-I (IGF-I) concentrations in Large White and Meishan pigs. Reproduction, Nutrition and Development 31 205-216.

MacLeod JN, Pampori NA \& Shapiro BH 1991 Sex differences in the ultradian pattern of plasma growth hormone concentrations in mice. Journal of Endocrinology 131 395-399.

Maes M, De Hertogh R, Watrin-Granger P \& Ketelslegers JM 1983 Ontogeny of liver somatotropic and lactogenic binding sites in male and female rats. Endocrinology 113 1325-1332.

Maiter D, Underwood LE, Maes M, Davenport ML \& Ketelslegers JM 1988 Different effects of intermittent and continuous growth hormone $(\mathrm{GH})$ administration on serum somatomedin-C/insulinlike growth factor I and liver GH receptors in hypophysectomized rats. Endocrinology 123 1053-1059.

Maiter D, Underwood LE, Martin JB \& Koenig JI 1991a Neonatal treatment with monosodium glutamate: effects of prolonged growth hormone (GH)-releasing hormone deficiency on pulsatile GH secretion and growth in female rats. Endocrinology 128 1100-1106.

Maiter D, Koenig JI \& Kaplan LM $1991 b$ Sexually dimorphic expression of the growth hormone-releasing hormone gene is not mediated by circulating gonadal hormones in the adult rat. Endocrinology 128 1709-1716.

Maiter D, Waler J, Adam E, Moats-Staats B, Mulumba N, Ketelslegers JM \& Underwood L 1992 Differential regulation by growth hormone $(\mathrm{GH})$ of insulin-like growth factor I and $\mathrm{GH}$ receptor/binding protein gene expression in rat liver. Endocrinology 130 3257-3264.

Maiter DM, Gabriel SM, Koenig JI, Russell WE \& Martin JB 1990 Sexual differentiation of growth hormone feedback effects on hypothalamic growth hormone-releasing hormone and somatostatin. Neuroendocrinology 51 174-180.

Martinoli MG \& Pelletier G 1991 Dihydrotestosterone (DHT) regulation of insulin-like growth factor II mRNA in neonatal rats. Peptides 12 1267-1271.

Martinoli MG, Oullet J, Rhéaume E \& Pelletier G 1991 Growth hormone and somatostatin gene expression in adult and aging rats as measured by quantitative in situ hybridization. Neuroendocrinology 54 607-615

Massa G, Igout A, Rombauts L, Frankenne F \& VanderschuerenLodeweyckx M 1993 Effect of oestrogen status on serum levels of growth hormone-binding protein and insulin-like growth factor-I in non-pregnant and pregnant women. Clinical Endocrinology 39 569-575.

Mathews LS, Enberg B \& Norstedt G 1989 Regulation of rat growth hormone receptor gene expression. Journal of Biological Chemistry 264 9905-9910.

Mauras N, Rogol AD \& Veldhuis JD 1990 Increased hGH production rate after low-dose estrogen therapy in prepubertal girls with Turner's syndrome. Pediatric Research 28 626-630.

Medrano JF \& Bradford GE 1991 Growth performance and plasma insulin-like growth factor I concentrations in sheep selected for high weaning weight. Journal of Animal Science 69 1912-1918.

Mercado M, Carlsson L, Vitangcol R \& Baumann G 1993 Growth hormone-binding protein determination in plasma: a comparison of immunofunctional and growth hormone-binding assays. Journal of Clinical Endocrinology and Metabolism 76 1291-1294.

Merimee TJ, Zapf J, Hewlett B \& Cavilli-Sforza LL 1987 Insulin-like growth factors in pygmies. New England Journal of Medicine 316 906-911.

Merimee TJ, Russell B, Quinn S \& Riley W 1991 Hormone and receptor studies: relationship to linear growth in childhood and puberty. Journal of Clinical Endocrinology and Metabolism $\mathbf{7 3}$ 1031-1037.

Metzger DL, Kerrigan JR \& Rogol AD 1994 Gonadal steroid regulation of the somatotropic axis during puberty in humans. Mechanisms of androgen and estrogen action. Trends in Endocrinology and Metabolism 5 290-296.

Mizobuchi M, Frohman MA, Downs TR \& Frohman LA 1991 Tissue-specific transcription initiation and effects of growth hormone $(\mathrm{GH})$ deficiency on the regulation of mouse and rat GH-releasing hormone gene in hypothalamus and placenta. Molecular Endocrinology 5 476-484.

Möldrup A, Petersen ED \& Nielsen JH 1993 Effects of sex and pregnancy hormones on growth hormone and prolactin receptor gene expression in insulin-producing cells. Endocrinology 133 $1165-1172$.

Murphy LJ \& Friesen HG 1988 Differential effects of estrogen and growth hormone on uterine and hepatic insulin-like growth factor I gene expression in the ovariectomized hypophysectomized rat. Endocrinology 122 325-332.

Oh Y, Nagalla SR, Yamanaka Y, Kim HS, Wilson E \& Rosenfeld RG 1996 Synthesis and characterisation of insulin-like growth factor-binding protein (IGFBP)-7. Recombinant human mac25 protein specifically binds IGF-I and -II. Journal of Biological Chemistry 271 30322-30325.

Ohlsson L, Isaksson O \& Jansson J-O 1987 Endogenous testosterone enhances growth hormone ( $\mathrm{GH}$ )-releasing factor-induced $\mathrm{GH}$ secretion in vitro. Journal of Endocrinology 113 249-253.

Ono M, Miki N \& Demura H 1991 Effect of antiserum to rat growth hormone $(\mathrm{GH})$-releasing factor on physiological GH secretion in the female rat. Endocrinology 129 1791-1796. 
Ono M, Miki N, Murata Y, Osaki E, Tamitsu K, Ri T, Yamada M \& Demura H 1995 Sexually dimorphic expression of pituitary growth hormone-releasing factor receptor in the rat. Biochemical and Biophysical Research Communications 216 1060-1066.

Owens PC, Johnson RJ, Campbell RG \& Ballard FJ 1990 Growth hormone increases insulin-like growth factor-I (IGF-I) and decreases IGF-II in plasma of growing pigs. Journal of Endocrinology 124 269-275.

Owens PC, Conlon MA, Campbell RG, Johnson RJ, King R \& Ballard FJ 1991 Developmental changes in growth hormone, insulin-like growth factors (IGF-I and IGF-II) and IGF-binding proteins in young growing pigs. Journal of Endocrinology 128 439-447.

Owens PC, Campbell RG, Francis GL \& Moyse KJ 1993 Effect of gender on regulation of insulin-like growth factors in pigs. Manipulating Pig Production IV 183.

Painson J-C \& Tannenbaum GS 1991 Sexual dimorphism of somatostatin and growth hormone-releasing factor signaling in the control of pulsatile growth hormone secretion in the rat. Endocrinology 128 2858-2866.

Painson J-C, Thorner MO, Kreig RJ \& Tannenbaum GS 1992 Short term adult exposure to estradiol feminizes the male pattern of spontaneous and growth hormone-releasing factor-stimulated growth hormone secretion in the rat. Endocrinology 130 511-519.

Pampori NA \& Shapiro BH 1994 Testicular regulation of sexual dimorphisms in the ultradian profiles of circulating growth hormone in the chicken. European Journal of Endocrinology 131 313-318.

Parker MW, Johanson AJ, Rogol AD, Kaiser DL \& Blizzard RM 1984 Effect of testosterone on somatomedin-C concentrations in prepubertal boys. Journal of Clinical Endocrinology and Metabolism $\mathbf{5 8}$ 87-90.

Pfeilschifter J, Scheidt-Nave C, Leidig-Bruckner G, Woitge HW, Blum WF, Wuster C, Haack D \& Ziegler R 1996 Relationship between circulating insulin-like growth factor components and sex hormones in a population-based sample of 50- to 80-year-old men and women. Journal of Clinical Endocrinology and Metabolism $\mathbf{8 1}$ 2534-2540.

Pietschmann P, Schernthaner G, Stephenson J, Lang I \& Templ H 1991 Enhanced growth hormone responses to growth hormone releasing hormone in male type I diabetic patients. Hormone and Metabolic Research 23 379-382.

Pincus SM, Gevers EF, Robinson ICAF, van der Berg G, Roelfsema F, Hartman ML \& Veldhuis JD 1996 Females secrete growth hormone with more process irregularity than males in both humans and rats. American Journal of Physiology 270 E107-E115.

Plotsky PM \& Vale W 1985 Patterns of growth hormone-releasing factor and somatostatin secretion into the hypophysial-portal circulation of the rat. Science 230 461-463.

Plouzek CA \& Trenkle A 1991 Growth hormone parameters at four ages in intact and castrated male and female cattle. Domestic Animal Endocrinology 8 63-72.

Postel-Vinay M-C 1976 Binding of human growth hormone to rat liver membranes: lactogenic and somatotropic sites. FEBS Letters 69 137-140.

Rajkovic IA, Valiontis E \& Ho KK 1994 Direct quantitation of growth hormone binding protein in human serum by a ligand immunofunctional assay: comparison with immunoprecipitation and chromatographic methods. Journal of Clinical Endocrinology and Metabolism 78 772-777.

Renaville R, Massart S, Sneyers M, Falaki M, Gengler N, Burny A \& Portetelle D 1996 Dissociation of increases in plasma insulin-like growth factor I and testosterone during the onset of puberty in bulls. Journal of Reproduction and Fertility 106 79-86.

Roberts CA, McCutcheon SN, Blair HT, Gluckman PD \& Breier BH 1990 Developmental patterns of plasma insulin-like growth factor-I concentrations in sheep. Domestic Animal Endocrinology 7 457-464.
Röpke R, Schams D, Schwartz FJ \& Kirchgessner M 1994

Growth-related hormones in plasma of bulls, steers and heifers given food with two different energy levels. Animal Production 59 367-377.

Rose SR, Municchi G, Barnes KM, Kamp GA, Uriate MM, Ross JI, Cassorla F \& Cutler GB Jr 1991 Spontaneous growth hormone secretion increases during puberty in normal girls and boys. Journal of Clinical Endocrinology and Metabolism 73 428-435.

Rosenbaum M \& Gertner JM 1989 Metabolic clearance rates of synthetic human growth hormone in children, adult women, and adult men. Journal of Clinical Endocrinology and Metabolism 69 821-824.

Rutanen E-M, Bohn H \& Seppälä M 1982 Radioimmunoassay of placental protein 12: levels in amniotic fluid, cord blood, and serum of healthy adults, pregnant women, and patients with trophoblastic disease. American Journal of Obstetrics and Gynecology 144 460-463.

Scanes CG, Dunnington EA, Bounomo FC, Donoghue DJ \& Siegel PB 1989 Plasma concentrations of insulin-like growth factor (IGF)-I and IGF-II in dwarf and normal chickens of high and low weight selected lines. Growth, Development and Aging 53 151-157.

Schwartz SM \& Kemnitz JW 1992 Age- and gender-related changes in body size, adiposity, and endocrine and metabolic parameters in free-ranging rhesus macaques. American Journal of Physical Anthropology 89 109-121.

Schwarz FJ, Röpke R, Schams D \& Kirchgessner M 1992 Effects of sex and growth on plasma concentrations of growth hormone, insulin-like growth factor-I and insulin in fattening Simmental cattle. Journal of Animal Physiology and Animal Nutrition 68 263-271.

Senaris RM, Lago F, Lewis MD, Dominguez F, Scanlon MF \& Dieguez C 1992 Differential effects of in vivo estrogen administration on hypothalamic growth hormone releasing hormone and somatostatin gene expression. Neuroscience Letters 141 123-126.

Shulman DI, Sweetland M, Duckett G \& Root AW 1987 Effect of estrogen on the growth hormone $(\mathrm{GH})$ secretory response to $\mathrm{GH}$-releasing factor in the castrate adult female rat in vivo. Endocrinology 120 1047-1051.

Simard J, Hubert J-F, Hosseinzadeh T \& Labrie F 1986 Stimulation of growth hormone release and synthesis by estrogens in rat anterior pituitary cells in culture. Endocrinology 119 2004-2011.

Sotiropoulos A, Goujon L, Simonin G, Kelly PA, Postel-Vinay MC \& Finidori J 1993 Evidence for generation of the growth hormonebinding protein through proteolysis of the growth hormone membrane receptor. Endocrinology 132 1863-1865.

Spagnoli A \& Rosenfeld RG 1996 The mechanisms by which growth hormone brings about growth. The relative contributions of growth hormone and insulin-like growth factors. Endocrinology and Metabolism Clinics of North America 25 615-631.

Styne DM 1991 The growth hormone secretory response to growth hormone releasing factor in the developing rhesus monkey. Journal of Medical Primatology 20 338-344.

Suikkari A-M, Seppälä M, Tiitinen A, Laatikainen T \& Stenman U-H 1991 Oral contraceptives increase insulin-like growth factor binding protein-1 concentrations in women with polycystic ovarian disease. Fertility and Sterility 55 895-899.

Tannenbaum GS \& Martin JB 1976 Evidence for an endogenous ultradian rhythm governing growth hormone secretion in the rat. Endocrinology 98 562-570.

Tannenbaum GS \& Ling N 1984 The interrelationship of growth hormone $(\mathrm{GH})$-releasing factor and somatostatin in generation of the ultradian rhythm of GH secretion. Endocrinology $\mathbf{1 1 5}$ 1952-1957.

Tanner JM 1962 Growth at Adolescence, edn 2. Blackwell: Oxford.

Tato L, Sagesse G, Cavallo L, Antoniazzi F, Carrias A, Pasquino AM \& Cisternino M 1995 Use of combined Gn-RH agonist and hGH therapy for better attaining the goals in precocious puberty treatment. Hormone Research 44 (Suppl 3) 49-54. 
Terry LC \& Martin JB 1981 The effects of lateral hypothalamicmedial forebrain stimulation and somatostatin antiserum on pulsatile growth hormone secretion in freely behaving rats: evidence for a dual regulatory mechanism. Endocrinology 109 622-627.

Thomas GB, Cummins JT, Sudbury AW, McCloud PI \& Clarke IJ 1991 Effect of restricted feeding on the relationship between hypophysial portal concentrations of growth hormone (GH)releasing factor and somatostatin, and jugular concentrations of $\mathrm{GH}$ in ovariectomized ewes. Endocrinology 128 1151-1158.

Thompson DL Jr, DePew CL, Ortiz A, Sticker LS \& Rahmanian MS 1994 Growth hormone and prolactin concentrations in plasma of horses: sex differences and the effects of acute exercise and administration of growth hormone-releasing hormone. Journal of Animal Science 72 2911-2918.

Thompson RG, Rodriguez A, Kowarski A, Migeon CJ \& Blizzard RM 1972 Integrated concentrations of growth hormone correlated with plasma testosterone and bone age in preadolescent and adolescent males. Journal of Clinical Endocrinology and Metabolism 35 334-337.

Tiong TS \& Herington AC 1991 Tissue distribution, characterization, and regulation of messenger ribonucleic acid for growth hormone receptor and serum binding protein in the rat. Endocrinology 129 $1628-1634$

Tiong TS, Freed KA \& Herington AC 1989 Identification and tissue distribution of messenger RNA for the growth hormone receptor in the rabbit. Biochemical and Biophysical Research Communications 158 141-148.

Tobar-Dupres ET, Frohman DP \& Davis SL 1993 Factors affecting circulating growth hormone binding protein in chickens. Poultry Science 72 2337-2346.

Ulloa-Aguirre A, Blizzard RM, Garcia-Rubi E, Rogol AD, Link K, Christie CM, Johnson ML \& Veldhuis JD 1990 Testosterone and oxandrolone, a nonaromatizable androgen, specifically amplify the mass and rate of growth hormone $(\mathrm{GH})$ secreted per burst without altering $\mathrm{GH}$ secretory burst duration or frequency or the $\mathrm{GH}$ half-life. Journal of Clinical Endocrinology and Metabolism 71 846-854.

Urman S, Kaler L \& Critchlow V 1985 Effects of hypothalamic periventricular lesions on pulsatile growth hormone secretion. Neuroendocrinology 41 357-362.

Veldhuis J 1996 Gender differences in secretory activity of the human somatotropic (growth hormone) axis. European Journal of Endocrinology 134 287-295.

Vestergaad M, Purup S, Henckel P, Tonner E, Glint DJ, Jensen LR \& Sejrsen K 1995 Effects of growth hormone and ovariectomy on performance, serum hormones, insulin-like growth factor-binding proteins, and muscle fiber properties of prepubertal Friesian heifers. Journal of Animal Science 73 3574-3584.

Wang H-S, Lee D-J \& Soong Y-K 1995 Serum levels of insulin-like growth factor I and insulin-like growth factor-binding protein-1 and -3 in women with regular menstrual cycles. Fertility and Sterility 63 1204-1209.

Webb CB, Szabo M \& Frohman LA 1983 Ectopic growth hormone-releasing factor and dibutyryl cyclic adenosine monophosphate-stimulated growth hormone release in vitro: effects of corticosterone and estradiol. Endocrinology 113 11911196.

Wehrenberg WB \& Giustina A 1992 Basic counterpoint: mechanisms and pathways of gonadal steroid modulation of growth hormone secretion. Endocrine Reviews 13 299-308.

Wehrenberg WB, Brazeau P, Luben R, Bohlen P \& Guillemin R 1982 Inhibition of the pulsatile secretion of growth hormone by monoclonal antibodies to the hypothalamic growth hormone releasing factor (GRF). Endocrinology 111 2147-2148.

Wehrenberg WB, Baird A, Ying S-Y \& Ling N 1985 The effects of testosterone and estrogen on the pituitary growth hormone response to growth hormone-releasing factor. Biology of Reproduction 32 369-375.

Weissberger AJ, Ho KKY \& Lazarus L 1991 Contrasting effects of oral and transdermal routes of estrogen replacement therapy on 24-hour growth hormone $(\mathrm{GH})$ secretion, insulin-like growth factor I, and GH-binding protein in postmenopausal women. Journal of Clinical Endocrinology and Metabolism 72 374-381.

Werner H, Koch Y, Baldino F Jr \& Gozes I 1988 Steroid regulation of somatostatin mRNA in the rat hypothalamus. Journal of Biological Chemistry 263 7666-7671.

Wiedemann E, Schwartz E \& Frantz AG 1976 Acute and chronic estrogen effects upon serum somatomedin activity, growth hormone, and prolactin in man. Journal of Clinical Endocrinology and Metabolism 42 942-952.

Winer LM, Shaw MA \& Baumann G 1990 Basal plasma growth hormone levels in man: new evidence for rhythmicity of growth hormone secretion. Journal of Clinical Endocrinology and Metabolism 70 $1678-1686$.

Yamamoto H, Sohmiya M, Oka N \& Kato Y 1991 Effects of aging and sex on plasma insulin-like growth factor I (IGF-I) levels in normal adults. Acta Endocrinologica 124 497-500.

Yeoh SI \& Baxter RC 1988 Metabolic regulation of the growth hormone independent insulin-like growth factor binding protein in human plasma. Acta Endocrinologica 119 465-473.

Zadik Z, Chalew SA, McCarter RJ Jr, Meistas M \& Kowarski AA 1985 The influence of age on the 24-hour integrated concentration of growth hormone in normal individuals. Journal of Clinical Endocrinology and Metabolism 60 513-516.

Zeitler P, Argente J, Chowen-Breed JA, Clifton DK \& Steiner RA 1990 Growth hormone-releasing hormone messenger ribonucleic acid in the hypothalamus of the adult male rat is increased by testosterone. Endocrinology 127 1362-1368.

Zorilla R, Simard J, Rhéaume E, Labrie F \& Pelletier G 1990 Multihormonal control of pre-pro-somatostatin mRNA levels in the periventricular nucleus of the male and female rat hypothalamus. Neuroendocrinology 52 527-536.

Received 10 November 1997

Accepted 23 January 1998 